\title{
The changing structure of international trade linked to global production systems: what are the policy implications?
}

Working Paper No. 33

\begin{abstract}
William Milberg
Policy Integration Department

World Commission on the Social Dimension of Globalization

International Labour Office

Geneva
\end{abstract}

May 2004 


\section{Copyright (C) International Labour Organization 2004}

Publications of the International Labour Office enjoy copyright under Protocol 2 of the Universal Copyright Convention. Nevertheless, short excerpts from them may be reproduced without authorization, on condition that the source is indicated. For rights of reproduction or translation, application should be made to the Publications Bureau (Rights and Permissions), International Labour Office, CH-1211 Geneva 22, Switzerland. The International Labour Office welcomes such applications.

Libraries, institutions and other users registered in the United Kingdom with the Copyright Licensing Agency, 90 Tottenham Court Road, London W1T 4LP [Fax: (+44) (0)20 7631 5500; email: cla@cla.co.uk], in the United States with the Copyright Clearance Center, 222 Rosewood Drive, Danvers, MA 01923 [Fax: (+1) (978) 750 4470; email: info@copyright.com] or in other countries with associated Reproduction Rights Organizations, may make photocopies in accordance with the licences issued to them for this purpose.

ISBN 92-2-116019-X (printed version)

ISBN 92-2-116020-3 (web version)

First published 2004

Cover:

The designations employed in ILO publications, which are in conformity with United Nations practice, and the presentation of material therein do not imply the expression of any opinion whatsoever on the part of the International Labour Office concerning the legal status of any country, area or territory or of its authorities, or concerning the delimitation of its frontiers.

The responsibility for opinions expressed in signed articles, studies and other contributions rests solely with their authors, and publication does not constitute an endorsement by the International Labour Office of the opinions expressed in them.

Reference to names of firms and commercial products and processes does not imply their endorsement by the International Labour Office, and any failure to mention a particular firm, commercial product or process is not a sign of disapproval.

ILO publications can be obtained through major booksellers or ILO local offices in many countries, or direct from ILO Publications, International Labour Office, CH-1211 Geneva 22, Switzerland. Catalogues or lists of new publications are available free of charge from the above address, or by email: pubvente@ilo.org

Visit our website: $\underline{w w w . i l o . o r g / p u b l n s}$

Printed by the International Labour Office, Geneva, Switzerland 


\section{The changing structure of international trade linked to global production systems: What are the policy implications?}

\section{Contents}

Foreword iii

Preface.

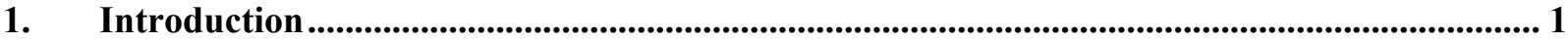

2. The globalization of production: trade and foreign direct investment .................................. 2

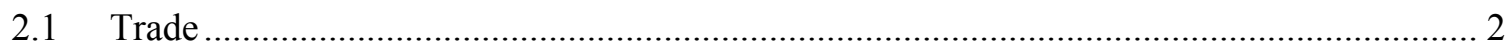

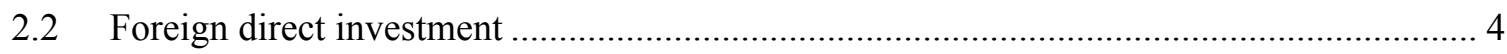

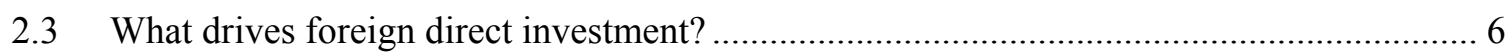

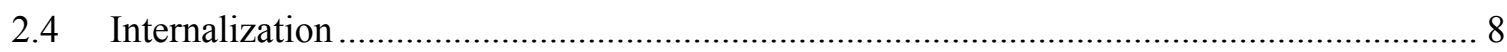

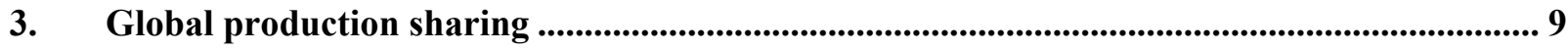

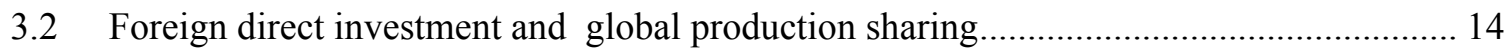

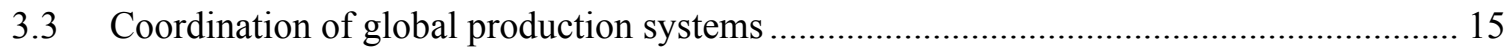

4. Implications of global production systems for the theory of trade .......................................... 16

4.1 International capital mobility and footloose-input production ....................................... 17

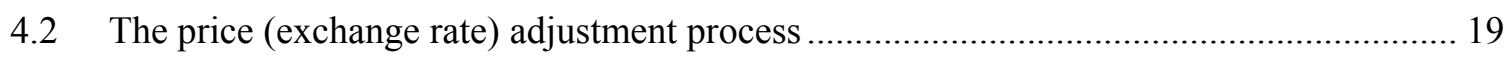

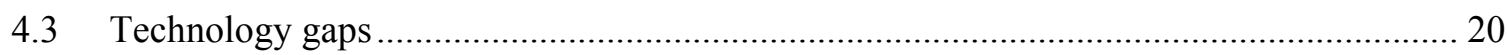

5. Implications of global production systems for the theory of foreign investment ................... 20

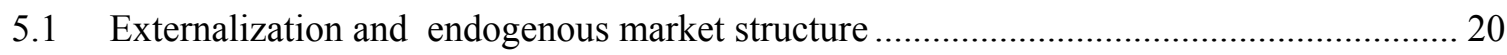

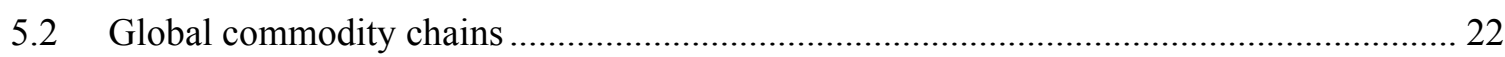

6. Endogenous asymmetry of market structure and its consequences ......................................... 24

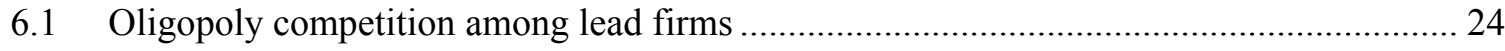

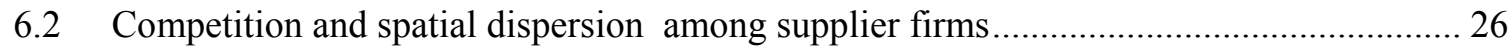

7. Consequences for labour and capital ....................................................................................... 31

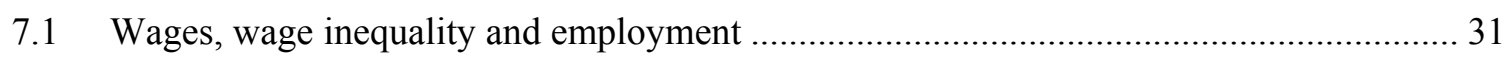

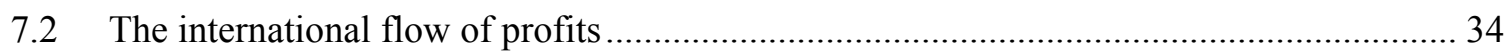

8. Policy implications of global production systems....................................................................... 38

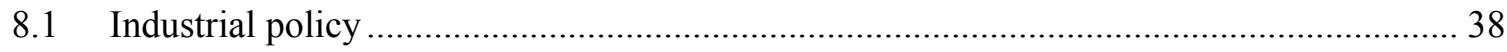

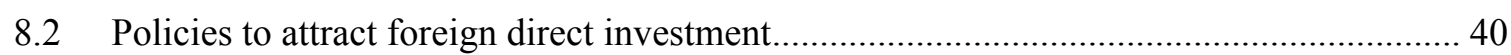

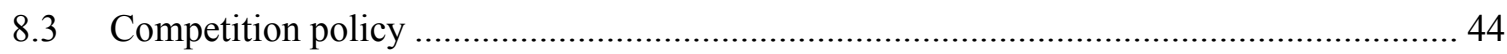

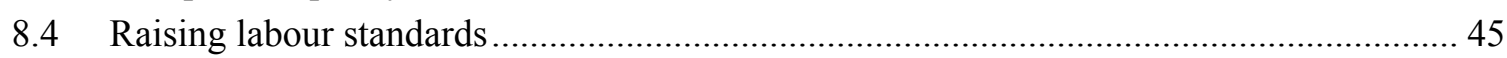

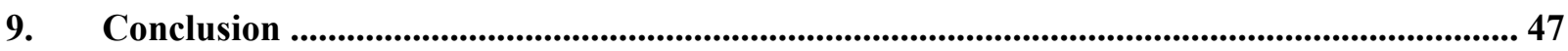

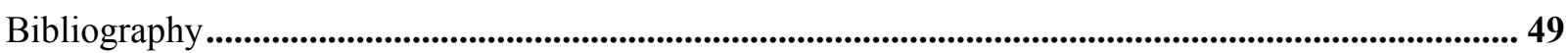





\title{
Foreword
}

In February 2002, the ILO established an independent World Commission on the Social Dimension of Globalization, co-chaired by President Tarja Halonen of Finland and President Benjamin Mkapa of Tanzania and comprising 26 eminent commissioners from a wide range of walks of life and different parts of the world, each serving in their individual capacity. Its broad goals were: to identify policies for globalization that reduce poverty, foster growth and development in open economies, and widen opportunities for decent work; to explore ways to make globalization inclusive, so that the process can be seen to be fair for all, both between and within countries; to promote a more focused international dialogue on the social dimension of globalization; to build consensus among key actors and stakeholders on appropriate policy responses; and to assist the international community forge greater policy coherence in order to advance both economic and social goals in the global economy.

The report of the World Commission, A fair globalization: Creating opportunities for all, was released on 24 February 2004. It is available on the Commission's website www.ilo.org/public/english/wcsdg/index.htm.

A secretariat was established by the ILO to support the Commission. Among other tasks, it compiled information and commissioned papers on different aspects of the social dimension of globalization. The aim was to provide the Commission with documentation and data on a wide range of options and opinions concerning subjects within its mandate, without committing the Commission or individual Commissioners to any particular position on the issues or policies concerned.

Material from this background work is being made available as working papers, as national and regional reports on meetings and dialogues, and in other forms. Responsibility for the content of these papers and publications rests fully with their authors and their publication does not constitute an endorsement by the World Commission or the ILO of the opinions expressed in them.

\author{
Gerry Rodgers \\ Director \\ Policy Integration Department
}





\title{
Preface
}

The Technical Secretariat to support the World Commission on the Social Dimension of Globalization first prepared a synthesis of ILO activities on the Social Dimension of Globalization (published as Working Paper No. 1 in this series). Documentation on the work and outcomes of other major commissions, an ideas bank, a database and knowledge networks of experts and social actors were subsequently developed. These networks have dealt with several topics, including: inclusion at the national level for the benefits of globalization to reach more people; local markets and policies; cross-border networks of production to promote decent work, growth and development; international migration as part of the Global Policy Agenda; international governance (including trade and finance); the relationship between culture and globalization; and values and goals in globalization. Gender and employment aspects were addressed throughout this work. The Reports on the Secretariat's Knowledge Network Meetings are available on the Commission's web site or as a special publication from the ILO (ISBN92-2-115711-1).

During the course of these activities, a number of substantive background papers were prepared, which are now made available for wider circulation in the Policy Integration Department's Working Paper series (Nos. 16 to 38), as well as on the Commission's website.

This paper was prepared by Professor Milberg of the New School University in New York. An earlier version of this paper was prepared for a Knowledge Network Meeting on Cross Border Networks of Production Systems, organized by Susan Hayter.

Professor Milberg argues in this paper, that the quantitative rise in world trade openness since 1980 may be less significant than the qualitative change in the structure of world trade, specifically the rise in intermediate goods trade resulting from the breaking up of the production process into different parts and locating these parts in different countries. His paper examines the extent of that structural change, its causes, and its implications for theory and policy. The increasing importance of trade in intermediate goods requires a new emphasis in the theories of international trade and investment toward a theory of the competitive struggle of absolute advantage and externalization. The challenge of industrial upgrading in global production systems will require industrial, competition and labour market policies at the national level aimed at generating the profit and wage growth needed to build skills, knowledge-based assets, infrastructure and demand that in turn gird longterm economic growth. In particular, a delicate balance must be struck between market power for firms needing profits to innovate, and competitive pressure that encourages knowledge-asset creation. Professor Milberg concludes that in past successful cases of industrial upgrading, inward foreign direct investment has not played a leading role and should not be relied on in this sense even with the provision of special incentives.

\author{
Rolph van der Hoeven \\ Manager, Technical Secretariat \\ World Commission on the Social Dimension of Globalization
}

May 2004 



\section{The changing structure of international trade linked to global production systems: what are the policy implications?}

\section{Introduction}

Most studies of economic globalization emphasize the rise in the degree of world trade openness since 1980, that is, the amount of trade in relation to overall economic activity. This quantitative rise, however, may be less significant than the qualitative change in the structure of world trade that has occurred in the same period, specifically the trade associated with the international "disintegration" of production, that is, the breaking up of the production process into different parts and locating these parts in different countries. This paper will examine the extent of that structural change, its causes, and its importance in the context of economic development.

The shift in the structure of international trade - both to more intermediates and increasingly outside the confines of the multinational enterprise - poses challenges to both theory and policy. The theoretical challenge is to the traditional theories of international trade and foreign direct investment. With the rise of international capital mobility and trade in intermediate goods, the theoretically harmonious world of comparative advantage gives way to the competitive struggle of absolute advantage and the relative desirability of a location for the production of a part of the production process. With respect to foreign investment, the internalization theory diminishes in importance, creating the need for an economic theory of externalization.

The policy challenge comes out of the fact that while global production sharing has apparently helped developing countries expand manufacturing export activity, the value added from that activity has not increased markedly over previous, commodity-based export regimes. This is because lead firms in global production networks outsource lower value-added activities, retaining control over production in the higher value added areas of "core competency". These areas are often characterized by higher technological and skill requirements, but also are commonly oligopolistic and subject to significant barriers to entry. The lower value added portions of many global production networks have low entry barriers and are characterized by ongoing entry by firms in countries that previously did not produce. Competition at this level can be so intense as to make it difficult to raise profits and wages. While wage stagnation affects the standard of living today, it is the difficulty of capturing rents for reinvestment purposes that poses the greatest challenge to economic development. The growth of foreign direct investment in developing countries has not solved the problem because most profits are repatriated, and foreign direct investment tends to lag rather than lead economic development. Countries should not make major concessions to attract foreign direct investment. Instead, to achieve the goal of skill and infrastructure development that is crucial for successful managerial capitalism (and which will likely attract foreign direct investment) countries should devise industrial and competition policies to meet their specific needs, and aimed at expanding rents from productive activity. It is the socially productive reinvestment of these rents on which economic development crucially hinges. 
This paper has nine sections. Section 2 is an overview of world trends in trade and foreign direct investment, with an emphasis on explaining the driving forces for foreign direct investment, and the slow growth in vertical as opposed to horizontal foreign direct investment. Section 3 considers global production sharing generally, stressing the growing importance of arm's length and other external forms of outsourcing. Sections 4 and 5 analyze the implications of global production systems for the theory of foreign trade and investment respectively. Section 6 reviews the evidence on market structure across global commodity chains. Section 7 then takes up the issue of consequences of globalized production for labour and capital, including the implications for wages and employment, and the international profit flow associated with globalized production. Section 8 assesses some policy issues directly relevant to the challenge of economic development resulting from globalized production. These relate to industrial policy, competition policy, policy towards inward foreign direct investment and labour market policies within the global production system. Section 9 briefly concludes.

\section{The globalization of production: trade and foreign direct investment}

Economic globalization is a two-pronged process: the globalization of finance and the globalization of production. The common feature of each of these parts is heightened international capital mobility. With widespread liberalization and computerization of financial markets, gross international capital flows have skyrocketed over the past 20 years. Consider the market for foreign exchange: in 1977, annual transactions in foreign exchange were US\$4.6 trillion. By 2001, transactions were running at a daily rate of US\$1,210 billion, representing a value equal to the annual value of world trade. ${ }^{1}$

\section{$2.1 \quad$ Trade}

If the globalization of finance has increased dramatically, the globalization of production has grown significantly. The globalization of production comprises both international trade and foreign direct investment. As is clear in figure 2.1, since the early 1980s the volume of world foreign direct investment (FDI) has grown more than that of international trade, which in turn has grown more than world output.

The globalization of production comes with great promise of a new phase of export growth from developing countries, whose inclusion in the process opens new markets and introduces new technologies. As world trade has expanded, both in absolute terms and in relation to world output, developing countries have maintained their share of world exports and have significantly expanded their share of world exports of manufactured goods. Figure 2.2 gives the share of world exports by various regions. The developing country share the same in 2001 as it was in 1963. Figure 2.3 shows the composition of developing country exports from 1965 through 1996, with a dramatic expansion in the share of manufactured goods, from around 10 per cent in 1975 to almost 75 per cent in 1996.

\footnotetext{
${ }^{1}$ Net capital flows (as opposed to gross flows) have arguably been inadequate or, worse, perverse, in the sense that debt repayment and profit repatriation by multinational enterprises has brought a flow from developing to the developed countries.
} 
Figure 2.1 World trade, foreign direct investment and GDP, 1970-1998 (index, 1970=100)

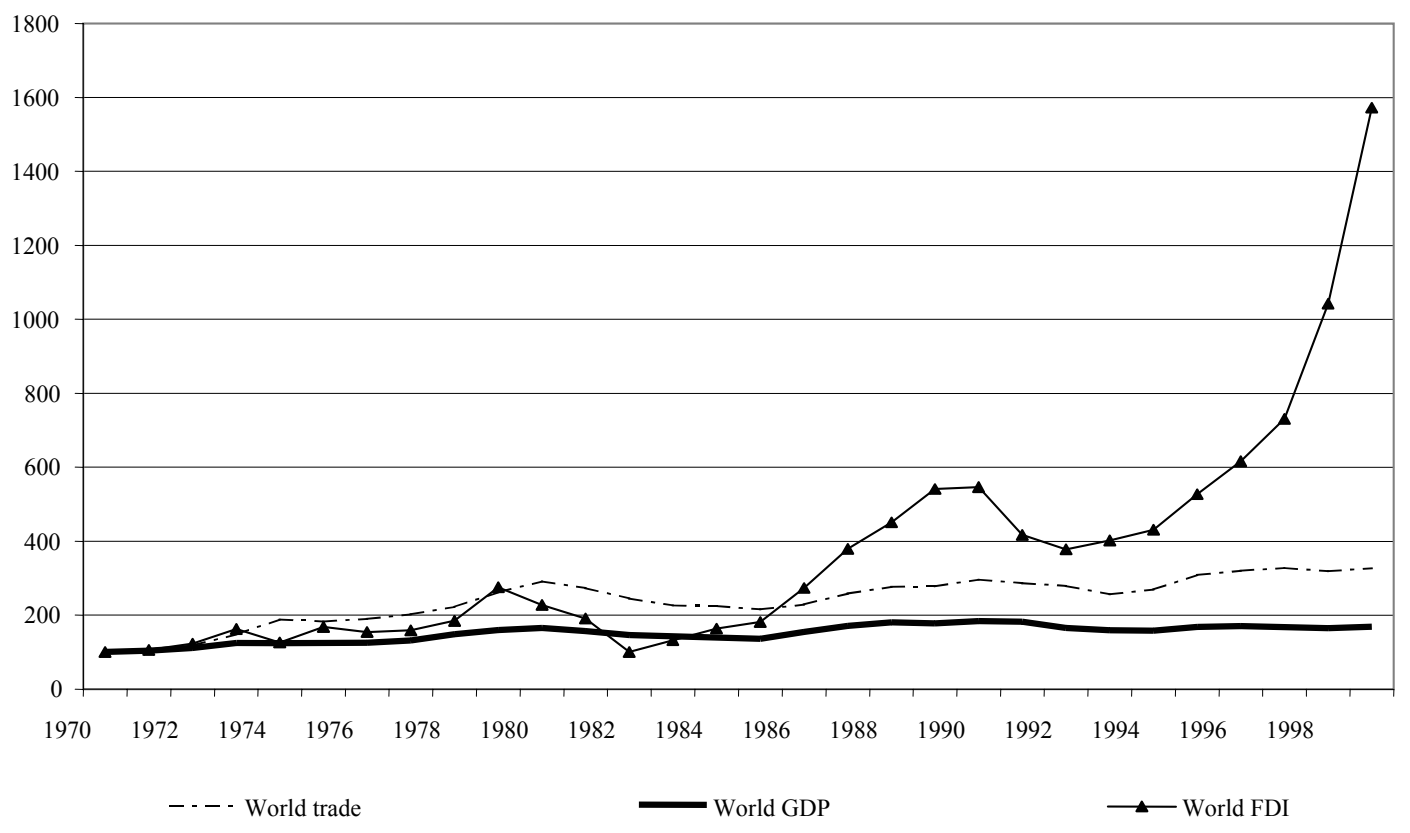

Source: IMF (2001), UNCTAD (2001).

Figure 2.2 Share of world exports by region, 1970-2000 (percentage share)

\begin{tabular}{lrrrrrrr}
\hline \multicolumn{1}{c}{ Share of world exports by region, 1970-2000 } & & & \\
\hline Region & 1948 & $\mathbf{1 9 5 3}$ & $\mathbf{1 9 6 3}$ & $\mathbf{1 9 7 3}$ & $\mathbf{1 9 8 3}$ & $\mathbf{1 9 9 3}$ & $\mathbf{2 0 0 1}$ \\
United States, Canada & 27.3 & 24.2 & 19.3 & 16.9 & 15.4 & 16.6 & 16.6 \\
Western Europe & 31.5 & 34.9 & 41.4 & 45.4 & 38.9 & 44.0 & 41.5 \\
Japan & 0.4 & 1.5 & 3.5 & 6.4 & 8.0 & 9.9 & 6.7 \\
Australia, New Zealand & 3.7 & 3.2 & 2.4 & 2.1 & 1.4 & 1.5 & 1.3 \\
Latin America & 12.3 & 10.5 & 7.0 & 4.7 & 5.8 & 4.4 & 5.8 \\
CE/ Europe/Baltic States/CIS & 6.0 & 8.1 & 11.0 & 9.1 & 9.5 & 2.9 & 4.8 \\
Africa & 7.3 & 6.5 & 5.7 & 4.8 & 4.4 & 2.5 & 2.4 \\
Middle East & 2.0 & 2.7 & 3.2 & 4.1 & 6.8 & 3.4 & 4.0 \\
Asia (excl. Japan) & 9.5 & 8.3 & 6.5 & 6.4 & 9.7 & 14.8 & 17.0 \\
Developed countries & 62.9 & 63.8 & 66.6 & 70.8 & 63.7 & 71.9 & 66.1 \\
Developing countries & 37.1 & 36.2 & 33.4 & 29.1 & 36.3 & 28.1 & 33.9 \\
\hline
\end{tabular}

Source: WTO (2002) 
Figure 2.3 Sectoral composition of developing country exports, 1965-1996 (percentage share)

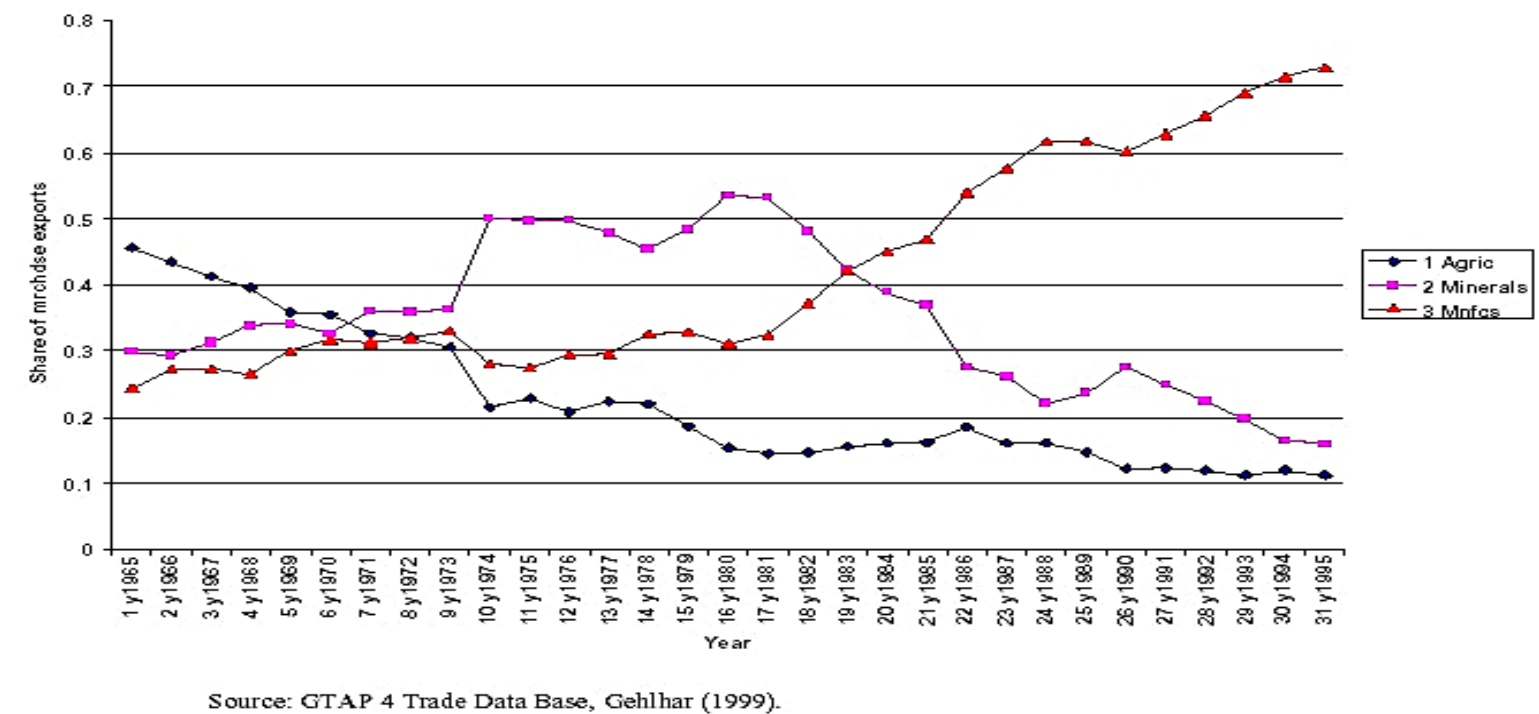

2.2 Foreign direct investment

The multinational enterprise is often viewed as a key driver of the globalization of production. This is understandable, since the existence of the multinational enterprise is, by definition, premised on some previous and significant (controlling) foreign investment. ${ }^{2}$ Moreover, the past 20 years have seen an explosive rise in the activities of multinational enterprises. According to the World Investment Report 2002:

Recent estimates suggest that there are about 65,000 TNCs today, with about 850,000 foreign affiliates across the globe. Their economic impact can be measured in different ways. In 2001, foreign affiliates accounted for 54 million employees compared to 24 million in 1990; their sales of almost $\$ 19$ trillion were more than twice as high as world exports in 2000, compared to 1990 when both were roughly equal; and the stock of outward foreign direct investment increased from $\$ 1.7$ trillion to $\$ 6.6$ trillion over the same period. Foreign affiliates now account for one-tenth of world GDP and one-third of world exports. ${ }^{3}$

The share of foreign direct investment in world gross capital formation rose by two-thirds between the early 1980s and the early 1990s; for developing countries, the increase was by three-quarters. Globally, foreign direct investment skyrocketed in the 1990s, although it dipped suddenly in 2001 as a result of world recession, asset deflation (especially stock market declines) and consequently a decline in value of a number of large mergers, mainly in Europe. Thus the decline in foreign direct investment flows was skewed towards developed countries. Foreign direct investment to developing countries rose from US\$8.4 billion in 1980 to US\$205 billion in 2001, and the developing country share of global foreign direct investment rose from 15 per cent in 1980 to 22 per cent in 1999-2001

${ }^{2}$ The convention for measurement purposes continues to be greater than 10 per cent ownership in a foreign asset. With the growth of stock markets (even in many developing countries) in the 1990s, the liquidity of FDI was raised, further blurring the distinction between portfolio and direct foreign investment. See Milberg (1999) for a more detailed discussion.

${ }^{3}$ UNCTAD (2002a), p. xv. 
(figure 2.4). This has not been enough of an increase, however, to make a change in the developing countries' share of the world stock of foreign investment, which has fluctuated around 35 per cent for the past 20 years (figure 2.5).

\section{Figure 2.4}

Developing countries' share of world foreign direct investment flows, selected years, 1970-2001

\begin{tabular}{|c|c|c|c|c|c|c|c|c|c|c|c|c|}
\hline & 1970 & 1975 & 1980 & 1985 & 1990 & 1995 & 1996 & 1997 & 1998 & 1999 & 2000 & 2001 \\
\hline Developed countries (US\$ billion) & 9.5 & 17.0 & 46.5 & 42.7 & 164.6 & 203.3 & 219.9 & 267.9 & 484.2 & 837.81 & $1,227.5$ & 503.1 \\
\hline Developing countries (US\$ billion) & 3.1 & 9.6 & 8.4 & 14.8 & 37.5 & 112.5 & 152.6 & 191.0 & 187.6 & 225.1 & 237.8 & 204.8 \\
\hline Developed countries (\%) & 75.3 & 63.8 & 84.7 & 74.1 & 81.2 & 61.5 & 57.0 & 56.0 & 69.7 & 77.0 & 82.3 & 68.4 \\
\hline Developing countries (\%) & 24.70 & 36.15 & 15.25 & 25.82 & 18.53 & 34.05 & 39.54 & 39.96 & 27.02 & 20.69 & 15.95 & 27.86 \\
\hline
\end{tabular}

Source: UNCTAD (2002a)

Figure 2.5

\begin{tabular}{lrrrrrrrrrr}
\hline \multicolumn{10}{c}{ Developing countries' share of world foreign direct investment stocks, selected years, 1980-2001 } \\
\hline & 1980 & 1985 & 1990 & 1995 & 1996 & 1997 & 1998 & 1999 & 2000 & 2001 \\
\hline Developed countries (US\$ billion) & 389.7 & 568.6 & $1,382.9$ & $2,021.3$ & $2,195.5$ & $2,295.8$ & $2,800.53,216.8$ & $4,124.2$ & $4,504.1$ \\
Developing countries (US\$ billion) & 245.8 & 344.4 & 484.9 & 849.9 & 988.8 & $1,147.6$ & $1,367.81,783.9$ & $2,002.1$ & $2,181.2$ \\
Developed countries (\%) & 61.32 & 62.27 & 73.89 & 69.42 & 67.80 & 65.31 & 65.7162 .94 & 65.90 & 65.79 \\
Developing countries (\%) & 38.68 & 37.73 & 26.11 & 30.58 & 32.20 & 34.69 & 34.2937 .06 & 34.10 & 34.21
\end{tabular}

Source: UNCTAD (2002a)

While the developing country share of world foreign direct investment flows has increased slightly, the role of foreign direct investment in the total inflow of foreign capital to developing countries has risen dramatically. Since the debt crises of the 1980s, direct investment has supplanted private debt or equity as well as government grants as the major channel of foreign capital inflows into developing countries (see figure 2.6). Again taking the average for 1999-2001 (to smooth the series given the year-to-year volatility in the data), we see that foreign direct investment in this period was 86 per cent of private foreign capital inflow and 71 per cent of total capital inflow to developing countries. The relative reliance on foreign direct investment to meet foreign capital needs could hardly be higher. 
Figure 2.6 Foreign direct investment in developing countries capital inflows, selected years 1970-2001, US\$ billion except where indicated

\begin{tabular}{|c|c|c|c|c|c|c|c|c|}
\hline & 1970 & 1980 & 1990 & 1995 & 1997 & 1999 & $2000^{a}$ & $2001^{b}$ \\
\hline Total & 11.2 & 82.8 & 98.5 & 257.2 & 343.7 & 290.7 & 261.1 & 196.5 \\
\hline Official & 5.4 & 35 & 55.9 & 53.9 & 39.9 & 52 & 35.3 & 36.5 \\
\hline Private & 5.8 & 47.8 & 42.6 & 203.3 & 303.9 & 238.7 & 225.8 & 160 \\
\hline FDI & 2.2 & 4.4 & 24.1 & 105 & 170.3 & 192 & 166.7 & 168.2 \\
\hline Equity & 0 & 0 & 2.8 & 36.1 & 30.2 & 27.6 & 50.9 & 18.5 \\
\hline Debt & 3.6 & 43.4 & 15.7 & 62.2 & 103.4 & 19.1 & 8.2 & -26.8 \\
\hline Official/Total (\%) & 48.2 & 42.3 & 56.8 & 21.0 & 11.6 & 17.9 & 13.5 & 18.6 \\
\hline Private/Official (\%) & 51.8 & 57.7 & 43.2 & 79.0 & 88.4 & 82.1 & 86.5 & 81.4 \\
\hline FDI/Total (\%) & 19.6 & 5.3 & 24.5 & 40.8 & 49.5 & 66.0 & 63.8 & 85.6 \\
\hline FDI/Private (\%) & 37.9 & 9.2 & 56.6 & 51.6 & 56.0 & 80.4 & 73.8 & 105.1 \\
\hline Equity/Total (\%) & 0.0 & 0.0 & 2.8 & 14.0 & 8.8 & 9.5 & 19.5 & 9.4 \\
\hline Equity/Private (\%) & 0.0 & 0.0 & 6.6 & 17.8 & 9.9 & 11.6 & 22.5 & 0.1 \\
\hline Debt/Total (\%) & 32.1 & 52.4 & 15.9 & 24.2 & 30.1 & 6.6 & 3.1 & -13.6 \\
\hline Debt/Private (\%) & 62.1 & 90.8 & 36.9 & 30.6 & 34.0 & 8.0 & 3.6 & -16.8 \\
\hline
\end{tabular}

\subsection{What drives foreign direct investment?}

The picture described above would indicate that foreign direct investment by multinational enterprises has become one of the true driving forces of globalization. What is motivating such high levels of foreign direct investment? There have been hundreds of empirical studies of the locational "determinants" of foreign direct investment. A typical econometric model regresses foreign direct investment on measures of economic activity, population, distance (both geographical and cultural, the latter using a language variable) and then adds a variable to capture human capital and perhaps, in the more recent versions, labour standards and political stability. Regulations on labour standards and tax concessions are often found to be insignificant. Kucera (2002) finds a significant negative effect of higher manufacturing wages/value added for a sample of 100 less developed countries. However, he does not find a negative effect of stronger union rights. This suggests the greater importance of non-cost effects of union rights on foreign direct investment, perhaps resulting from greater political and social stability. ${ }^{4}$

This result is less surprising when placed in the context of the traditional distinction between horizontal and vertical foreign direct investment. Horizontal foreign direct investment is also called "market-seeking" in that it involves a replication of productive capacity in the foreign location, presumably for sales there. Two conditions are necessary to induce such foreign direct investment. First the foreign market must already exist or be about to develop. Second, replication of production on foreign soil must be preferable to export from home. Typically, this second condition depends on an absence of significant economies of scale and the presence of high tariffs in the foreign market. For this reason such horizontal foreign direct investment is often termed "tariff hopping". Certainly most foreign direct investment to developed countries is aimed at better serving host markets, and some foreign direct investment in developing countries is driven by similar reasoning

\footnotetext{
${ }^{4}$ On tax concessions, see Wheeler and Mody (1992). See also Hanson (2000) for case studies that support the Wheeleer and Mody results.
} 
- Brazil being a well-documented example. ${ }^{5}$ Thus econometric studies looking at all foreign direct investment will likely find host market GDP as the most significant determining variable.

Vertical foreign direct investment involves capital movement aimed at more efficient backward linkages, either in production or in natural resources. "Efficiency-seeking" vertical foreign direct investment is the movement abroad of productive resources with the aim of lowering costs. It can be driven by a variety of factors, including lower labour costs, lower taxes on profits, low or lax standards on labour or the environment. These advantages must more than offset the tariffs and transportation costs incurred as a result of the international movement of any parts, components or assembled goods. Efficiency-seeking foreign direct investment is typically viewed as investment in low-wage countries, but it is not exclusively so. Considerable United States direct investment in Canada, for example, serves to produce or assemble parts used in goods solely in the United States and Japanese direct investment in Ireland, for example, has been understood as driven by that country's relatively efficient labour force and proximity to the European Union market.

"Resource-seeking" vertical foreign direct investment is driven by the desire of lead firms to control supplies of natural resources or primary commodities used in the production of other goods. This motivated the traditional structure of colonial and neo-colonial foreign investment, led by Britain in the 1870-1913 period and by the United States after the Second World War, but continues to be a factor in foreign direct investment today for sectors which are resource-intensive, such as steel or fabricated metal products. Some analysts have recently added "strategic-asset seeking" as an additional motive for foreign direct investment, referring to cases such as European investment in Silicon Valley. Such investment is vertical, but would focus on forward rather than the backward linkages typically associated with vertical foreign direct investment. ${ }^{6}$

Figure 2.7 provides a crude breakdown of global foreign direct investment along the lines of the traditional taxonomy of the motives for foreign direct investment, that is, between horizontal and vertical foreign direct investment. As figure 2.7 shows, the accumulated stock of vertical foreign direct investment has increased gradually over time, although at approximately the same rate as horizontal foreign direct investment in the 1990s, leaving its share unchanged. ${ }^{7}$

\footnotetext{
${ }^{5}$ On China, see Braunstein and Epstein (2002). On Brazil, see Evans (1995).

${ }^{6}$ Dunning (2000).

${ }^{7}$ Hanson et al. (2001) find evidence of increased verticality in United States outward foreign direct investment in the 1990s compared to the 1980s.
} 
This dominance of horizontal foreign direct investment shown in the figure would explain why horizontal investment swamps the dynamics of vertical investment in most econometric studies. Another reason these studies have often not found cost differences to be a significant driver of globalized production is that such movements in relative costs may trigger production sharing through external rather than intra-firm channels, an issue we consider in detail below. ${ }^{8}$

Figure 2.7 Horizontal and vertical foreign direct investment inward stocks, 1980-2001

\begin{tabular}{lcccccccccc}
\hline & 1980 & 1985 & 1990 & 1995 & 1996 & 1997 & 1998 & 1999 & $\mathbf{2 0 0 0}$ & $\mathbf{2 0 0 1}$ \\
\hline $\begin{array}{l}\text { Horizontal FDI } \\
\text { (US \$ billion) }\end{array}$ & 351.4 & 527.1 & $1,303.8$ & $1,930.9$ & $2,100.6$ & $2,210.6$ & $2,764.2$ & $3,167.8$ & $4,054.5$ & $4,447.1$ \\
$\begin{array}{l}\text { Vertical FDI } \\
\text { (US\$ billion) }\end{array}$ & 284.2 & 386.0 & 564.1 & 940.3 & $1,083.8$ & $1,232.9$ & $1,404.2$ & $1,833.1$ & $2,071.9$ & $2,238.2$ \\
Horizontal FDI (\%) & 55.29 & 57.73 & 69.80 & 67.25 & 65.97 & 64.20 & 66.31 & 63.34 & 66.18 & 66.52 \\
Vertical FDI (\%) & 44.71 & 42.27 & 30.20 & 32.75 & 34.03 & 35.80 & 33.69 & 36.66 & 33.82 & 33.48 \\
\hline $\begin{array}{l}\text { Source: } \\
\text { Note: }\end{array}$ & $\begin{array}{l}\text { UNCTAD (2002). } \\
\text { Horizontal group consists of all of the developed countries and Brazil but without Canada and Ireland. Vertical group }\end{array}$
\end{tabular}

\section{$2.4 \quad$ Internalization}

There is a commonality across the three motives for foreign direct investment in the traditional taxonomy. In all cases, firms have decided to maintain the foreign operation within the firm. This is the process of internalization, according to which firms will expand their own operations when they control an asset - often an intangible or knowledge-based asset - that allows them to earn above normal profits rather than seek another firm to supply the downstream, upstream or horizontal product or service.

The internalization motive is rooted in the very logic of the capitalist firm itself: firms are organizations that exist distinct from markets precisely because they can organize production at a lower cost than would be incurred if all aspects of the production process took place in markets. In a classical article entitled "The Nature of the Firm", Coase (1937) identified lower transactions costs as the source of the advantage of firm rather than market-based organization of production. This rationale for the existence of the firm was extended to explain foreign direct investment, that is, as the simultaneous desire of firms to expand markets and retain the benefits of the firm organization.

Coase's insights have formed the basis for the theory of the multinational enterprise for the past three decades. Hymer (1976), and later others, described the transnational firm as a non-market institution in the Coasian sense: the international extension of the firm reflects its apparent organizational superiority, perhaps because of the transactions cost savings it brings compared to market transactions. Such savings, or rents, could result from the

\footnotetext{
${ }^{8}$ For example, Brainard and Riker (1997) find little substitution of foreign for domestic labour by multinational enterprises when foreign labour costs fall. They consider only multinational enterprises and their affiliates, thus leaving out any arm's length international outsourcing. See. Feenstra (1998) for a similar criticism of studies of outsourcing that only include foreign investment data, that is that exclude arm's length subcontracting
} 
firm's intangible assets related to technology, production process, product design, management, labour relations, marketing, service, or any other dimension of the production or delivery of a good or service. While the internalization of international operations through foreign investment is a result of the relative inefficiency of the market, the protection of such knowledge assets by keeping them internal to the firm is widely recognized as the prime reason for firms to invest abroad rather than serve foreign markets in other ways, such as exports or even through licensing or subcontracting. Today, the advantages of internalization are still seen as the key explanation of foreign direct investment. ${ }^{9}$

\section{Global production sharing}

Given the sheer magnitude of their operations, multinational enterprises are, not surprisingly, at the centre of current discussions of globalization. Their ability to break up the production process into parts and integrate this process across many nations has come to be the symbol of globalization itself. Ford's "world car", for example, has parts produced in 14 countries and assembly operations in nine countries. ${ }^{10}$ Such increased verticality may account for the fact that international trade and foreign direct investment, once seen as substitute means of serving foreign markets, are now complementary, with foreign direct investment often resulting in more imports and exports.

Ironically, because foreign direct investment is measured so precisely and for so many countries, analysts tend to see globalization through a foreign direct investment lens. Like the proverbial drunk who searches for his lost keys under the streetlight only because that is where he can see best, economists have overemphasized the relevance of foreign direct investment for economic development - both in terms of its direct role in developing country production processes and in terms of its distinctiveness from the process of international trade.

A different picture emerges if we focus more generally on the change in the structure of international trade over the past 20 years and in particular the rise in intermediate goods in overall international trade, whether it is done within firms as a result of foreign direct investment or through arm's length subcontracting. Such trade has risen more rapidly than trade in final goods, and it is the defining manifestation of globalized production, or what has variously been termed "outsourcing"; "the international disintegration of production" (Feenstra, 1998); "the slicing up of the value chain" (Krugman, 1995); "global production sharing" (Yeats, 2001); "the international integration of production" (UNCTAD, 1993); "vertical integration"; "vertical specialization" (Hummels et al. 1998); "fragmentation" (Arndt and Kierzkowski, 2001); "intra-product specialization" (Arndt, 1997), and "the rise of global production networks" (Ernst et al., 2002) or global value chains" (Sturgeon, 2001). We begin by evaluating the extent of the process, and then turn to an analysis of its causes and consequences.

\footnotetext{
${ }^{9}$ Dunning (2000) for many years embellished the internalization theory with two other types of advantages that would explain foreign direct investment: ownership and location.

${ }^{10}$ UNCTAD (1993).
} 
Because international production sharing is not measured explicitly in the international trade data (with one exception discussed below), economists have applied a variety of techniques to measure its extent. All studies support the same general conclusion: such processes have become more prevalent over the past decade and have reached significant levels in relation to industrial production. Feenstra and Hanson (1999) measure the share of (estimated) imported inputs in total intermediate good use in United States manufacturing and find that this share rose from 6.5 per cent in 1972 to 8.5 per cent in 1979 to 11.6 per cent in 1990. A narrower measure of outsourcing, which considers only those inputs that are purchased from the same two-digit SIC industry as the good being produced, showed a similar acceleration between 1972 and 1990, as figure 3.8 shows. ${ }^{11}$

Figure 3.8 United States outsourcing, broad and narrow measures, 1972-1990

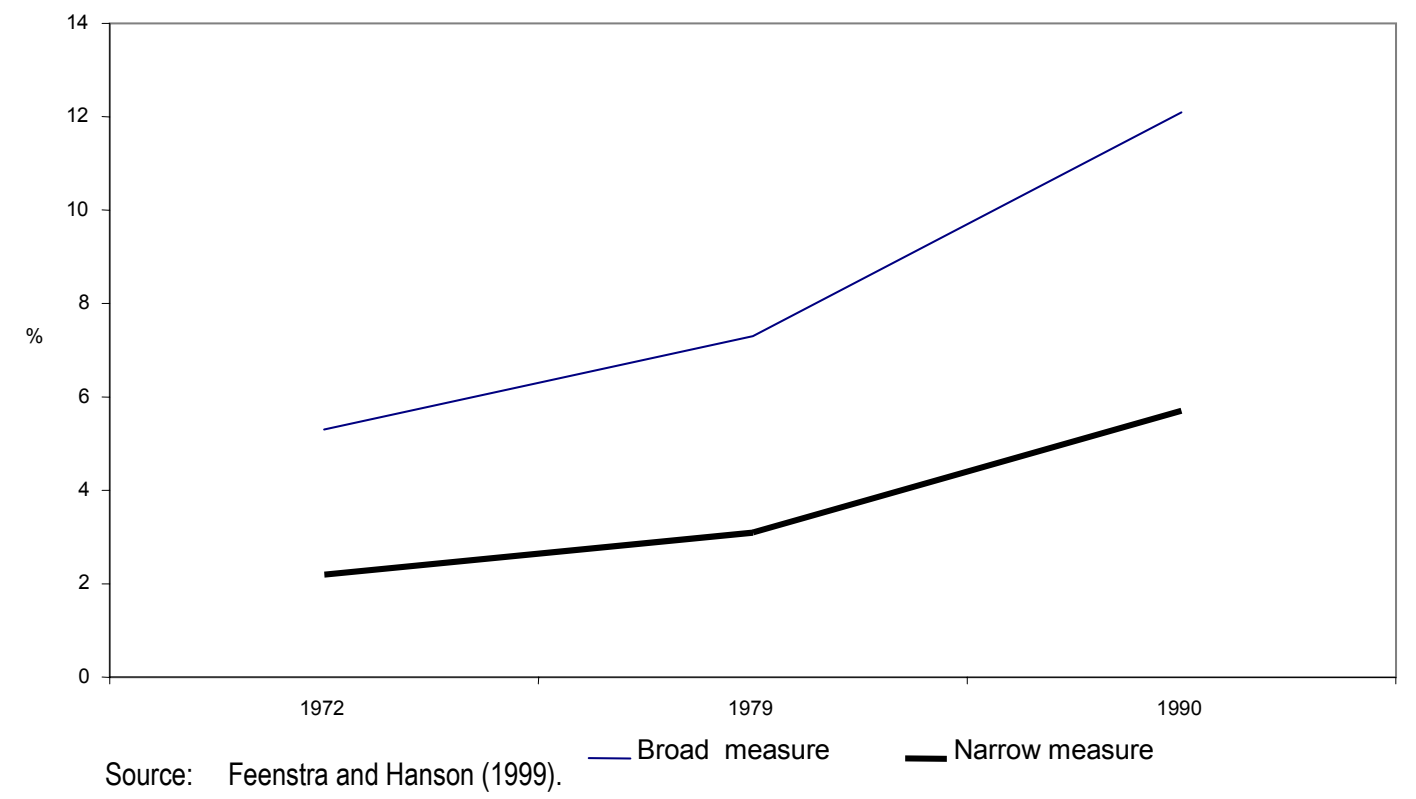

Campa and Goldberg (1997) provide slightly more recent evidence and look at two-digit manufacturing sectors for Canada, Japan, the United Kingdom, and the United States in the mid-1970s, mid-1980s and mid-1990s. They measure imported inputs as a share of total inputs using input-output data. They find a monotonic increase across industries in all countries. Moreover, the rate of increase in imported input use across industries was relatively constant, implying that "industries with relatively high levels of import penetration or imported input use in the early 1970s retained their relatively high reliance on imported inputs through the mid-1990s". (Campa and Goldberg, 1997, p. 4). Figure 3.9 summarizes the results for the four countries over time. Note that in almost every manufacturing sector, the levels of imported input use are lower for the United States and Japan than for the other two, and yet the rate of increase over time is clear in these cases as well.

11 Where: imported inputs=[input purchases of good $\mathrm{j}$ by industry $\mathrm{i}$ ]*[imports of good $\mathrm{j}$ /consumption of good $\mathrm{j}]$. 
A detailed study of the machinery and transportation equipment sector (SITC 7), found very striking patterns in the globalization of production (Yeats, 2001). Machinery and transportation equipment accounts for about 50 per cent of trade in manufactures, and is used by the author because under SITC revision 2 (implemented by most countries in the early 1980s), it is the only industrial category for which trade in parts and components are distinguished from trade in assembled goods. Since the early 1980s, trade in parts and components in this sector has increased more rapidly than trade in finished goods. As a result, the share of trade of parts and components trade in overall trade of SITC 7 rose to 30 per cent in 1995, from 26.1 per cent in 1978. Figure 3.10 shows that this increase in the export of parts and components as a share of total trade in machinery and transportation equipment was found across the industrialized countries, but was most dramatic in Japan, which greatly expanded its global production system in developing Asia. The flip side of this is seen in figure 3.11, which gives the imports of various countries and regions of parts and components of SITC 7 shipped from OECD countries. This shows a shift in the destination of OECD exports of parts and components between 1978 and 1995, with less going to Europe and more to developing countries - presumably for assembly and re-export. China and the rest of East Asia in particular experienced large increases in the share of imports received, indicating their huge role in the production of machinery and transportation equipment. Almost three-fourths of Asian imports in telecommunications equipment now consists of components for further processing and then export. In 1996 East-Asian exports for SITC 7 were estimated at US\$178 billion.

Figure 3.9 Imported inputs as a share of total intermediate inputs, Canada, Japan, United Kingdom, United States (percentages)

\begin{tabular}{|c|c|c|c|}
\hline \multirow[t]{2}{*}{ Country } & 1974 & 1984 & 1993 \\
\hline & \multicolumn{3}{|c|}{ All manufacturing industries } \\
\hline Canada & 15.9 & 14.4 & 20.2 \\
\hline Japan & 8.2 & 7.3 & 4.1 \\
\hline United Kingdom & 13.4 & 19.0 & 21.6 \\
\hline \multirow[t]{2}{*}{ United States } & 4.1 & 6.2 & 8.2 \\
\hline & \multicolumn{3}{|c|}{ Chemical and allied products } \\
\hline Canada & 9.0 & 8.8 & 15.1 \\
\hline Japan & 5.2 & 4.8 & 2.6 \\
\hline United Kingdom & 13.1 & 20.6 & 22.5 \\
\hline \multirow{2}{*}{ United States } & 3.0 & 4.5 & 6.3 \\
\hline & \multicolumn{3}{|c|}{ Industrial machinery (non-electrical) } \\
\hline Canada & 17.7 & 21.9 & 26.6 \\
\hline Japan & 2.1 & 1.9 & 1.8 \\
\hline United Kingdom & 16.1 & 24.9 & 31.3 \\
\hline \multirow[t]{2}{*}{ United States } & 4.1 & 7.2 & 11.0 \\
\hline & \multicolumn{3}{|c|}{ Electrical equipment and machinery } \\
\hline Canada & 13.2 & 17.1 & 30.9 \\
\hline Japan & 3.1 & 3.4 & 2.9 \\
\hline United Kingdom & 14.9 & 23.6 & 34.6 \\
\hline \multirow[t]{2}{*}{ United States } & 4.5 & 6.7 & 11.6 \\
\hline & \multicolumn{3}{|c|}{ Transportation equipment } \\
\hline Canada & 29.1 & 37.0 & 49.7 \\
\hline Japan & 1.8 & 2.4 & 2.8 \\
\hline United Kingdom & 14.3 & 25.0 & 32.2 \\
\hline United States & 6.4 & 10.7 & 15.7 \\
\hline
\end{tabular}

Source: Campa and Goldberg (1997). 
Figure 3.10 Exports of parts and components as a share (\%) of total exports of machinery and transportation

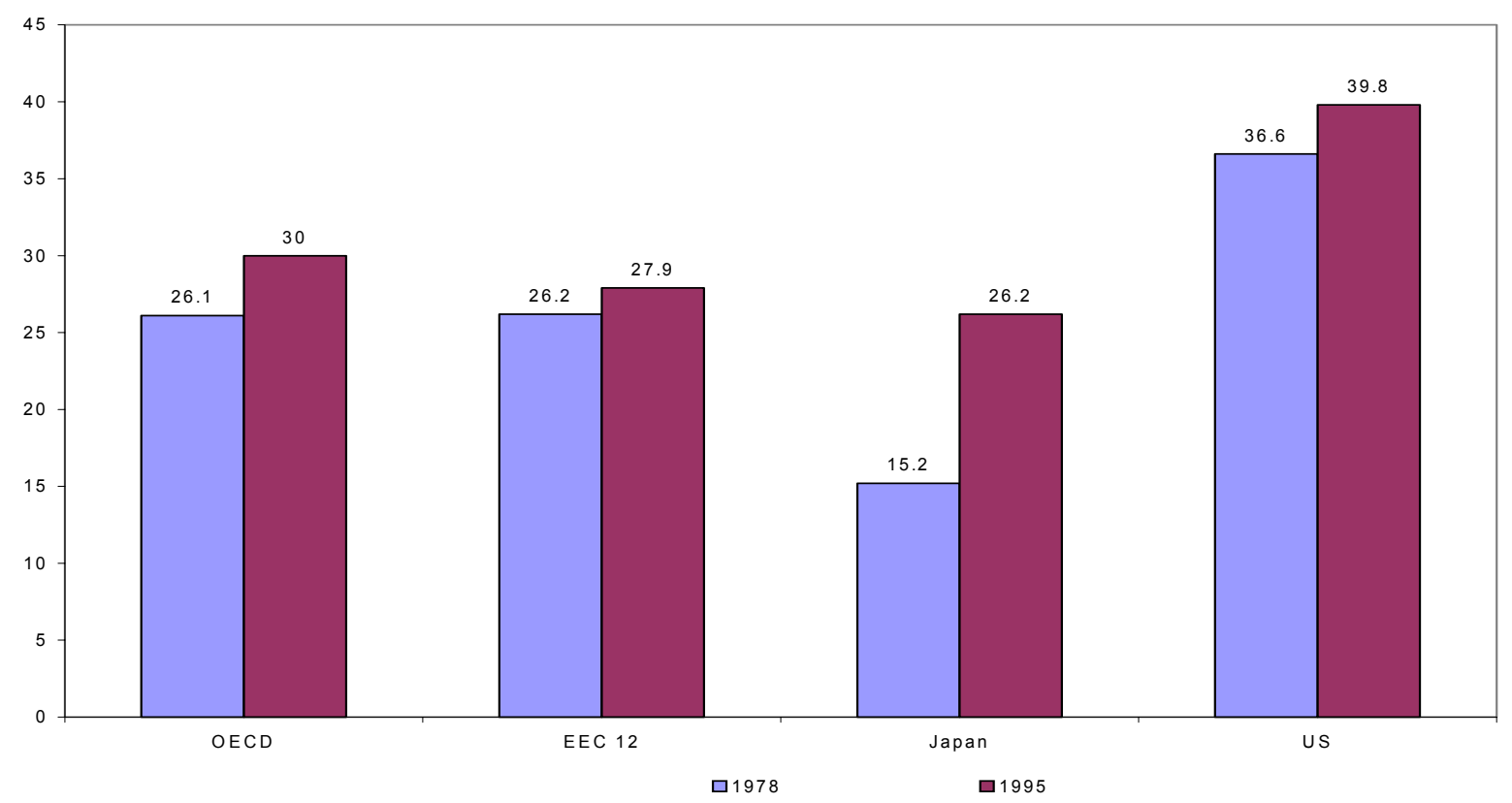

Figure 3.11 Imports of parts and components as a share of total OECD exports of machinery and transportation equipment, 1978 and 1995, selected countries and regions

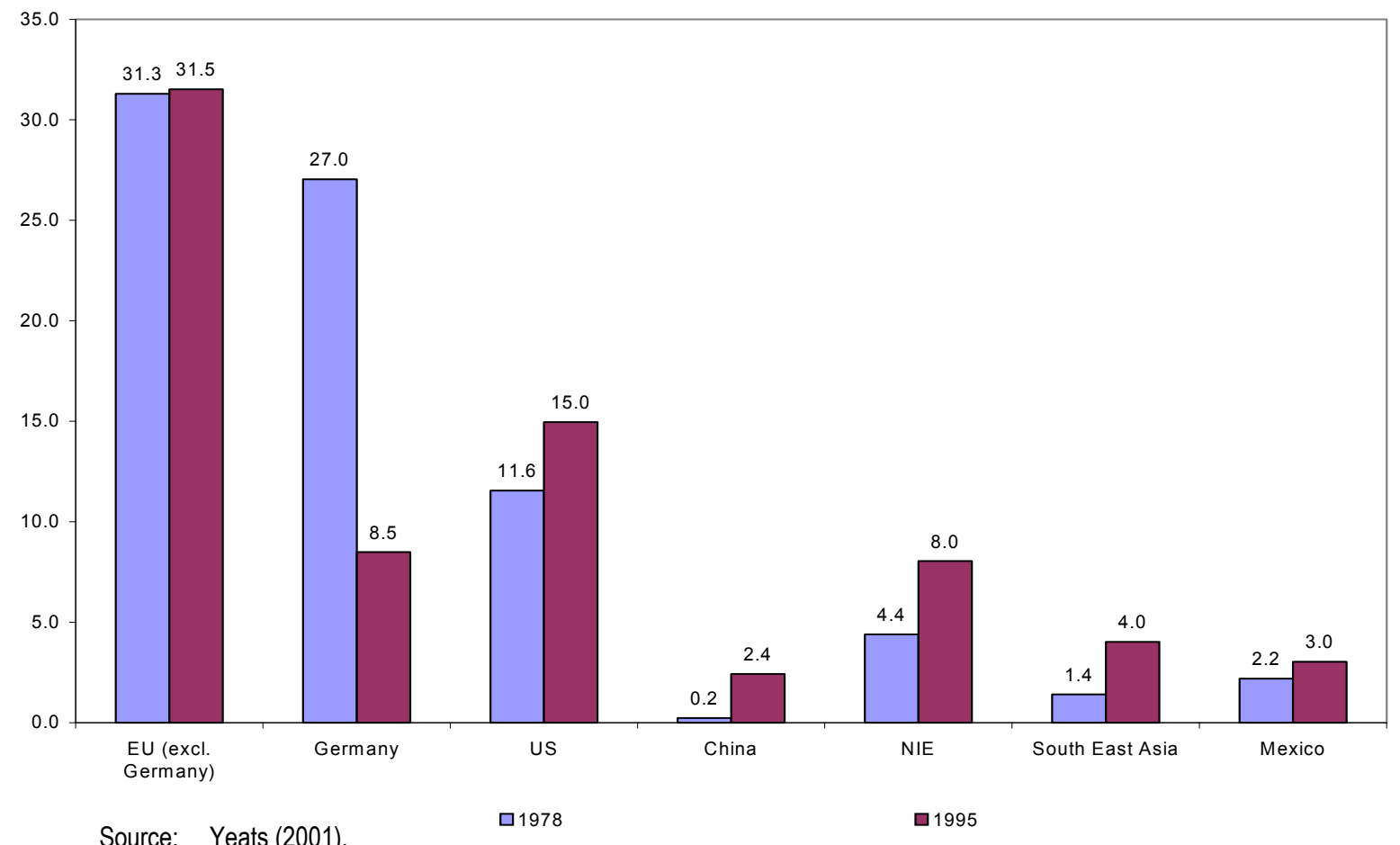

Note: NIE includes Hong Kong, the Republic of Korea, Singapore, and Taiwan; South-East Asia includes Indonesia, Malaysia and Thailand. 
Other studies use a more trade-oriented measure of production sharing. One measure is "processing trade", that is the amount of imports of intermediates that are then processed and re-exported. Feenstra and Hanson (2001) report that this rose dramatically in the 1990s for China and for the United States with respect to the European Union periphery countries of Greece, Ireland, Portugal and Spain. Hummels et al. (1998) define "vertical specialization" as "the amount of imports embodied in goods that are exported", and find an average increase of 20 per cent in this measure for OECD countries between the 1960s and 1990s. Specific industries showed huge increases: vertical specialization in Japanese-Asian trade in electronics increased nine fold between 1986 and 1995.

Although the trade data permit a precise measure of global production sharing only for a few industries, there is now massive evidence that global production sharing is being undertaken in a wide variety of sectors, including textiles and apparel, consumer electronics, transportation and machinery, light consumer goods industries such as toys and even services as diverse as sales and finance. For example, a description of the sourcing network for production of the Barbie Doll gives a sense of how complex the global production system can be even for seemingly simple and low value added products:

The raw materials for the doll (plastic and hair) are obtained from Taiwan and Japan. Assembly used to be done in those countries, as well as the Philippines, but it has now migrated to lower cost locations in Indonesia, Malaysia, and China. The moulds themselves come from the United States, as do additional paints used in decorating the dolls. Other than labour, China supplies only the cotton cloth used for dresses. Of the \$2 export value for the dolls when they leave Hong Kong for the United States, about 35 cents covers Chinese labour, 65 cents covers the cost of materials, and the remainder covers transportation and overhead, including profits earned in Hong Kong. The dolls sell for about \$10 in the United States, of which Mattel earns at least \$1, and the rest covers transportation, marketing, wholesaling and retailing in the U.S. The majority of value-added is therefore from United States activity. The dolls sell worldwide at the rate of two dolls every second, and this product alone accounted for $\$ 1.4$ billion in sales for Mattel in 1995. ${ }^{12}$

There may be limits to the degree to which production processes can be dispersed across the globe. The opposite of such dispersion, so-called "spatial clustering" or "agglomeration" has been observed as the result of scale economies, high transportation costs and preferential trade arrangements. According to Venables (2002):

Vertical specialisation is extremely transport sensitive. Products cross borders many times, so small transport costs and trade frictions cumulate into large overall effects. This suggests that trade will develop primarily between clusters of countries with good communication and transport links.

That is, dispersion of production networks is more likely when transport costs are low, and clustering more likely when transport costs are high. Venables hypothesizes that clustering may increase in the future as new technologies promote the spread of "just-in-time" production processes. In addition to these technical factors limiting dispersion, organizational considerations have certainly confined the process for those aspects of corporate activity associated with research and development (R\&D), finance and strategic and market planning. ${ }^{13}$

12 Feenstra (1998, p. 7).

13 Doremus et al. (1998). 


\subsection{Foreign direct investment and global production sharing}

Because of the simultaneous expansion of the activities of transnational corporations on the one hand, and the growth in trade in intermediates on the other, one might assume that the latter is driven by the former, and that the growth in the share of intermediate goods trade in total world trade identified in all the studies reviewed above is largely the result of a growth in intra-firm trade, that is, international trade that takes place within multinational enterprises. Surprisingly, the share of trade that is intra-firm has been relatively constant for the past 25 years, implying that it has grown at the same rate as the overall volume of trade. For example, while the share of intra-firm trade in total United States trade is high, it has been has been remarkably constant for over 25 years, at around 35 per cent for exports and 42 per cent for imports over the period 1977-98 (see figure 3.12). According to the figure, intra-firm trade in fact constituted a smaller share of United States exports and imports in 1998 as compared to 1984. A similar pattern is found in the intra-firm trade from Japan and Sweden, the only two other countries for which reliable intra-firm trade data exist (see addendum to figure 3.12 below).

Figure 3.12 Intra-firm trade as a share of total trade, United States, 1977-98, per cent share of total exports and imports

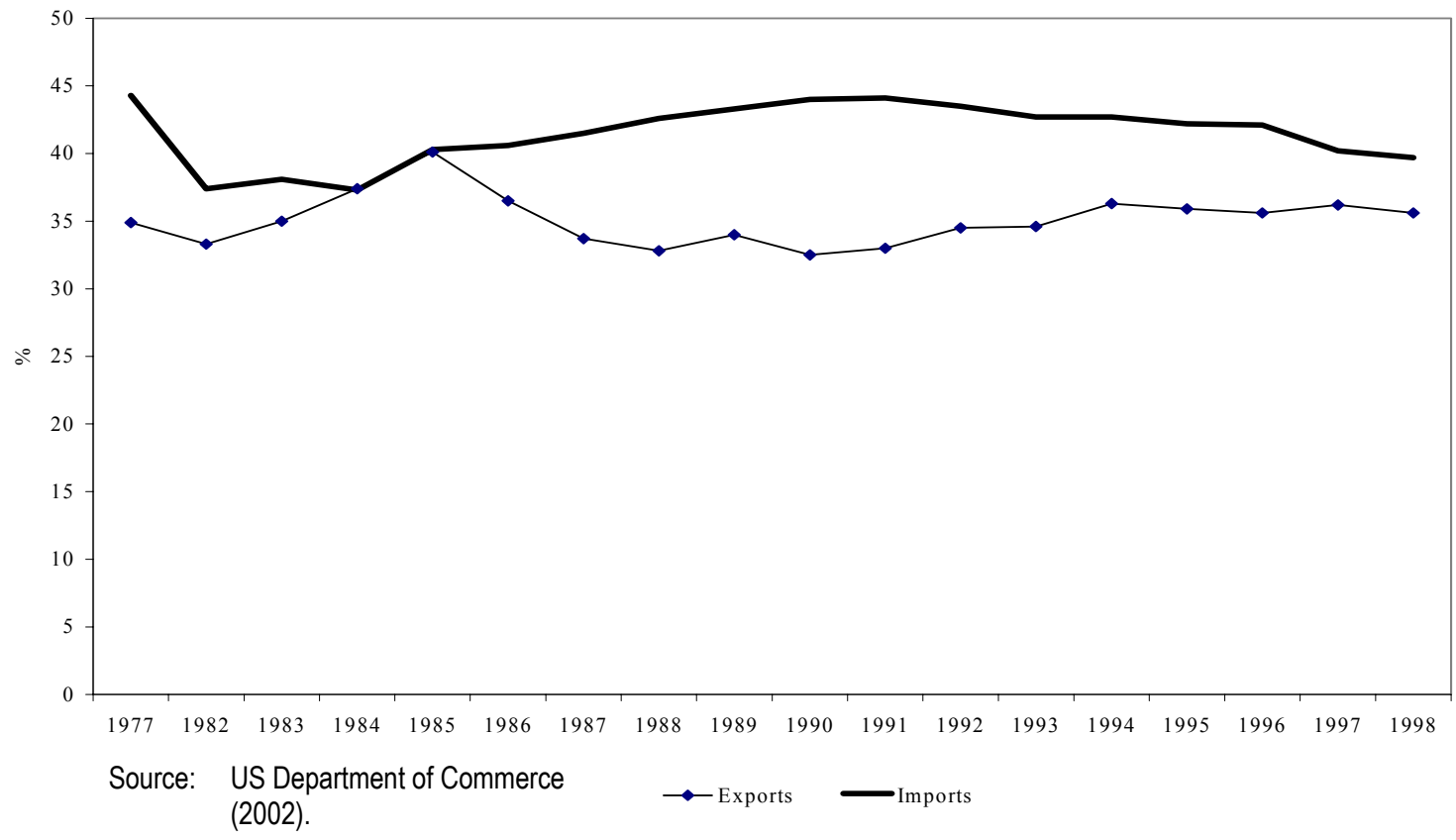

Addendum: Cross-border intra-firm trade, Sweden and Japan, share in total exports \& imports

\begin{tabular}{lrrrr}
\hline & 1983 & 1989 & 1992 & 1993 \\
\hline Japan & & & & \\
Exports & 22.5 & 24.5 & 26.9 & 25.0 \\
Imports & 5.1 & 15.3 & 14.8 & 14.0 \\
Sweden & & & 1986 & 1994 \\
Exports & & & 38.0 & 38.0 \\
Imports & & & 3.0 & 9.0 \\
\hline Source: & Milberg (1999) & & &
\end{tabular}


The high but constant share of intra-firm trade in total trade by the United States, Japan and Sweden indicates that despite the stunning increase in the transnational activity of large firms - measured by employment, production or sales - such firms find it increasingly desirable to outsource internationally in an arm's length rather than non-arm's length (intra-firm) relation. Specifically, with the share of intermediate goods trade increasing and the share of intra-firm trade constant, the rise in the share of trade in intermediates must be the result of arm's length transactions, that is, international outsourcing outside the confines of the multinational enterprise. This suggests that another reason that econometric analyses of the determinants of foreign direct investment tend to find an insignificant relation between production costs and capital movements is that increasingly efficiency-seeking foreign direct investment is being substituted with arm's length subcontracting.

\title{
3.3 Coordination of global production systems
}

The dichotomy between arm's length outsourcing and the intra-firm production sharing by multinational enterprises does not capture the variety of organizational forms linking lead and supplier firms in a "network" or "quasi-hierarchy". These relations mix elements of intra-firm hierarchy and arm's length market relations. A key to the hierarchical form of components supply is the trust established across divisions of the firm over time. Such trust is important in guaranteeing a reliability of supply and flexibility in the response to exogenous shocks, such as shifts in demand or design. Within the global production system, trust is sometimes established through personal contacts. According to one study of the apparel industry:

\begin{abstract}
Pre-existing social relationships facilitate global production networks by reducing the risks of misunderstanding and opportunism. In the global apparel industry, ethnic ties appear to do just that, as Asian entrepreneurs based in the United States are linking up to factories in Asia at a much higher rate than other ethnicities, and are more able to establish the necessary connections required to ensure reliable transactions and to reduce quality and delivery risks. ${ }^{14}$
\end{abstract}

There is a combination of factors driving this growth in global production systems. The shift from hierarchy to market or quasi-market is driven by lead firms in their efforts to lower costs, raise efficiency and speed of delivery, increase flexibility and risk sharing, and "improve the incentive and control structure of hierarchical organization" (Semmlinger, 1991, p.105). The relative gain from vertical disintegration makes apparent some limitations of the vertical organization that characterized successful firms for the entire twentieth century. Powell (1990) mentions three weaknesses of vertically integrated firms: "an inability to respond quickly to competitive changes in international markets; resistance to process innovations that alter the relationships between different stages of the production process; and systematic resistance to the introduction of new products" (Powell, 1990, pp. 318-319).

Figure 3.13 presents a simple taxonomy of forms of international outsourcing, broken out by the degree of coordination between lead and supplier firms. There is a rich literature analyzing the global production networks, but for our purposes we focus on how this form of industrial organization is captured in the analysis of trade and investment. From the perspective of international trade statistics, the network form is most like a market, since

14 Christerson and Appelbaum (1995, p. 1371). 
international trade along such a network is considered an arm's length exchange. In addition to arm's length international outsourcing of intermediate goods, there has been a rise in trade in final goods at the wholesale level, that is, goods whose production is complete except for marketing and retailing. These goods are imported by large retailers (for example, Wal Mart, the Gap) or by so-called "manufacturers without factories" or "fab-less" firms, such as Nike, Calvin Klein or Fischer-Price, who import goods fully assembled - but containing the lead firm label or package - from a foreign producer or intermediary. In these cases, the value added by the lead firm comes in the areas of design, marketing or retailing.

\section{Figure 3.13 Coordination in global production systems}

\begin{tabular}{l|lll}
\hline Coordination & Type of goods flow & Type of capital flow & Type of industry \\
\hline $\begin{array}{l}\text { None } \\
\text { (market) }\end{array}$ & Arm's length trade & None & $\begin{array}{l}\text { Low design specification } \\
\text { requirement (e.g. standard } \\
\text { apparel, electronics, toys) }\end{array}$ \\
$\begin{array}{l}\text { Some } \\
\text { (network or quasi- } \\
\text { hierarchy) }\end{array}$ & Arm's length trade & $\begin{array}{l}\text { Some, mainly technological or } \\
\text { knowledge-based }\end{array}$ & $\begin{array}{l}\text { Low technological requirement, } \\
\text { high design requirement } \\
\text { (e.g. non-standard apparel, } \\
\text { footwear, electronics) }\end{array}$ \\
$\begin{array}{l}\text { Complete (firm or hierarchy) } \\
\text { Intra-firm trade }\end{array}$ & Foreign direct investment & $\begin{array}{l}\text { High technological and design } \\
\text { requirement (e.g. autos) }\end{array}$ \\
\hline
\end{tabular}

In other respects, the relation among firms in networks or quasi-hierarchies is closer to that of a single firm and its majority-owned affiliate. Information may be shared between lead and supplier firms that traditionally would be kept within the firm. Technical and communications support might be provided by the lead firm in order to smooth the delivery of supplies. Production blueprints may even be provided to developing country supplier firms. ${ }^{15}$ Japanese subcontractors, for example, use "long-term close relations with suppliers", including "rich information sharing". ${ }^{16}$ Nolan et al. (2002) describe such suppliers as "the external firm of the large global corporations", an ambiguous term that reflects precisely this organizational arrangement between market and hierarchy. This means that while there may be no measured foreign direct investment between lead and supplier firms in a network, there is possibly significant capital flow, be it of the tangible or intangible kind.

\section{Implications of global production systems for the theory of trade}

The rise in trade in intermediate goods in manufacturing constitutes a fundamental shift in the structure of international trade and poses a challenge to economists' understanding of how countries fit into the international division of labour. In the traditional theory of international trade, the direction of trade (that is, which countries produce what goods for export) is determined by the principle of comparative advantage. According to this principle, countries will specialize in the production and export of the good or goods for which its relative productivity advantage exceeds that of the foreign country.

15 Tybout (2000, p. 36).

16 Holmstrom and Roberts (1998, pp. 80-82), cited in Williamson (2002, p. 190). 
Since, by definition, each country will always have a relative productivity advantage in at least one sector, the principle of comparative advantage generates the happy result that all countries will be able to participate successfully in international trade, in the sense that they will benefit from such trade and be able to generate export revenue equal to the value of imports. That is, free trade will be beneficial and balanced for all countries, even for those who have higher costs in all sectors. Paul Krugman (1991) sums up this view nicely:

\begin{abstract}
International competition does not put countries out of business. There are strong equilibrating forces that normally ensure that any country remains able to sell a range of goods in world markets, and to balance its trade on average over the long run, even if its productivity, technology, and product quality are inferior to those of other nations [...]. Both in theory and in practice, countries with lagging productivity are still able to balance their international trade, because what drives trade is comparative rather than absolute advantage (Krugman, 1991, pp. 811, 814).
\end{abstract}

The "equilibrating forces" to which Krugman refers are the price adjustments that should occur in the event that trade is not balanced, originally described by David Hume in 1746 and today known as Hume's "price-specie-flow mechanism". Under a gold standard, a country running, say, a trade deficit, will experience a net outflow of specie (gold), leading to a decline in the money supply and thus the price level. This lowering of prices improves the competitiveness of the nation's goods, and the specie and price movements end when trade is balanced. Today, it the exchange rate that is supposed to adjust, depreciating in the face of a trade deficit and appreciating to spur adjustment from a surplus.

The globalization of production and finance has rendered irrelevant some of the key assumptions of the Ricardo-Hume model of trade. We will focus briefly on three of these. One is the assumption of no international movement of capital or input production. The second is the Humean adjustment process that converts comparative advantage into money cost differences that make international trade actually happen. The third is the non-uniform distribution of knowledge-based assets across firms and countries.

\title{
4.1 International capital mobility and footloose-input production
}

The rise of capital mobility and the increased share of trade in intermediate goods imply that capital or, analogously, the production of the intermediate inputs, can move to where it is most profitable. What determines the international division of labour and the direction of international trade will depend not on comparative advantage, but on the desirability of a location.

Ricardo, writing in the early nineteenth century, had been clear in his justification of the assumption of no international capital mobility. After stating the implications for the location of production if capital is fully mobile - that all factors of production would move from England to Portugal in his famous example - Ricardo then asserts that the assumption of no international capital mobility is reasonable because, "the natural disinclination which every man has to quit the country of his birth and connexions, and entrust himself with all his habits fixed, to a strange government and new laws, check the emigration of capital". Ricardo adds that: "These feelings, which I should be sorry to see weakened, induce most 
men of property to be satisfied with a low rate of profits in their own country, rather than seek a more advantageous employment for their wealth in foreign nations." ${ }^{17}$

In the twenty-first century, the assumption of no international capital mobility and no international movement in the location of the production of inputs is at odds with the undeniable forces of globalization described in this paper. ${ }^{18}$ The introduction of an internationally mobile factor of production into the theory of trade reduces the relevance of comparative advantage in the determination of trade patterns. With free capital mobility, a good will be produced only where it is most profitable, typically where unit labour costs are lowest. At the extreme, say if one country has an absolute advantage in all goods (that is, if unit costs are lower in the production of all goods), this country will attract foreign capital, reducing foreign production and employment to zero in equilibrium. Caves (1982, p. 55) describes the implications of such a situation:

In general, the more mobile are factors of production, the less does comparative advantage have to do with patterns of production. If all factors are more productive in the United States than in Iceland and nothing impeded their international mobility, all economic activity would be located in the United States.

Jones (1980, p. 258) makes a similar point:

\begin{abstract}
Although each nation can, by the law of comparative advantage, find something to produce, it may end up empty-handed in its pursuit of industries requiring footloose factors. Once trade theorists pay proper attention to the significance of these internationally mobile productive factors, the doctrine of comparative advantage must find room as well for the doctrine of "relative attractiveness", where it is not necessarily the technical requirements of one industry versus another that loom important, it is the overall appraisal of one country versus another as a safe, comfortable, and rewarding location for residence of footloose factors.
\end{abstract}

Relative productivities or costs will not necessarily play a determining role, and in this sense absolute advantage will be the operative principle, not comparative advantage. In his 2000 Ohlin Lectures, published in book form as Globalization and the Theory of Input Trade, Ronald Jones (2000) explains:

The idea of comparative advantage is linked to the notion that inputs are trapped by national boundaries, so that the only decision that needs to be made concerns the allocation within the country of these inputs [...]. [A] world in which some inputs are internationally mobile or tradable is a world in which [...] the doctrine of comparative advantage, with its emphasis on the question of what a factor does within the country, needs to share pride of place with the doctrine of absolute advantage guiding the question of where an internationally mobile factor goes. (p. 136) [...]. Once international mobility in an input is allowed, absolute advantage

\footnotetext{
${ }^{17}$ Ricardo, 1981 [1817], pp. 136-137.

18 Twentieth century trade theorists were able to avoid the issue of international capital mobility because of Samuelson's (1949) development of the factor price equalization theorem, which implied that even in the absence of international movements of factors of production, free trade in goods will bring about an equalization in the remuneration of productive factors. Thus all the welfare benefits of international exchange could be gained without any international capital (or labour) mobility.
} 
becomes a concept that takes its rightful place alongside comparative advantage in explaining the direction of international commerce. (p. 7)

\subsection{The price (exchange rate) adjustment process}

The second fundamental weakness of the theory of comparative advantage in the twenty-first century is its presumption of a well-functioning Hume price adjustment mechanism. As financial markets, including foreign exchange markets, have been liberalized, exchange rates have increasingly been driven by financial market fluctuations, and certainly have not responded to "fundamentals" like the balance of trade. The delinking of exchange rates from the trade balance has led to persistent trade imbalances and the unlikelihood that comparative cost differences will be transformed into a situation of absolute money cost and price differences across countries.

A country running a trade deficit as the result of high labour standards and costs, for example, cannot expect a market-driven depreciation in the medium run. Trade imbalances since 1980 among the OECD countries have been larger and more persistent than earlier in the post-war era. Figure 4.14 shows the cumulative current account balance for major OECD countries and the number of consecutive years the current account remained in surplus or deficit. These are the countries with the most highly developed and liberal financial markets, and thus where current account adjustment would be expected to be most efficient. The magnitude (in relation to GDP) and the persistence of current account imbalances is greater in every case, except Canada in the 1992-2001 period, than it was in the 1972-1981 span. $^{19}$

Figure 4.14 Cumulative current account balances, selected countries and periods

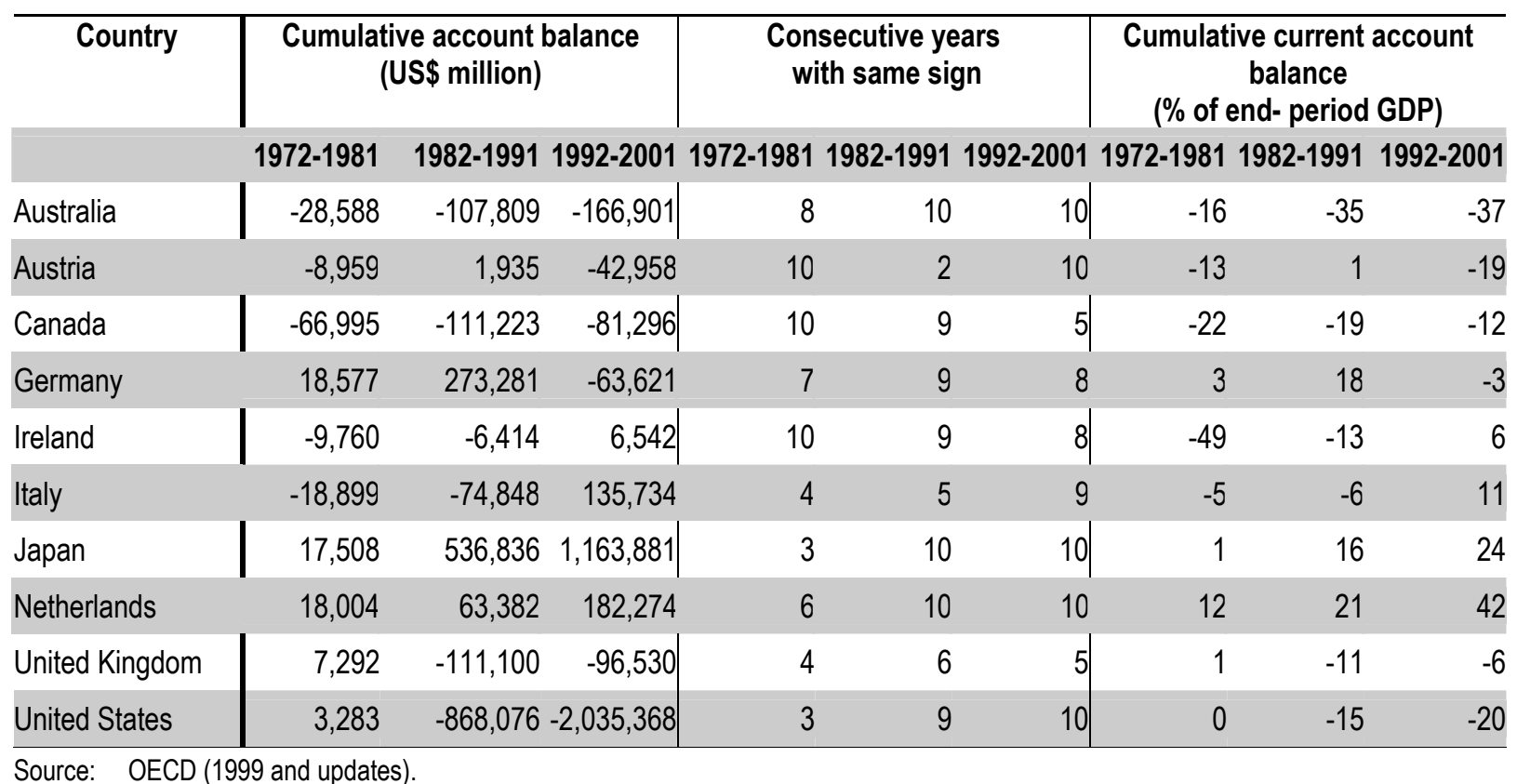

\footnotetext{
${ }^{19}$ Supporting this result, empirical studies finds that the Marshall-Lerner conditions - the conditions required if devaluation is to bring a trade balance improvement - are often not satisfied for the industrialized countries or developing countries. See, for example, Rose (1991).
} 
In addition to the issues of international capital mobility, footloose input production and financial market liberalization, the growing role of non-price competition, in particular competition over new products or processes, have further reduced the effectiveness of the Hume mechanism in balancing trade and thus the relevance of comparative advantage. With persistent differences in technology or knowledge across firms and countries, writes Alice Amsden:

The price of land, labour and capital no longer uniquely determines competitiveness. The market mechanism loses status as its sole arbiter, deferring instead to institutions that nurture productivity. Because a poor country's lower wages may prove inadequate against a rich country's higher productivity, the model of "comparative advantage" no longer behaves predictably: latecomers cannot necessarily industrialize simply by specializing in a low-technology industry. Even in such an industry, demand may favour skilled incumbents. ${ }^{20}$

Firms seek profits and growth by creating and protecting a knowledge advantage over rivals, be it through innovation, foreign direct investment, international outsourcing, interfirm cooperation or state subsidies. International differences in social institutions - from systems of innovation and finance to tax treatment of corporate profits, to labour market regulations and even the scope of the welfare State - can affect both productivity and non-price dimensions of traded goods, in turn affecting the competitiveness of particular sectors and of the overall trading position of a national economy. A firm's export market share will depend on the overall pattern of these advantages. Market share adjustments lead to income changes, and these, in turn, are likely to be more important for the evolution of trade than any cost-based changes, such as exchange rate adjustments. The Humean mechanism may be operative to some degree, but it is dominated by the absolute advantages resulting from knowledge-based differences in productivity. The diminished role for price competition because of the dominance of knowledge-based differences further raises the likelihood that trade imbalances will persist, as noted above.

\section{Implications of global production systems for the theory of foreign investment}

\subsection{Externalization and endogenous market structure}

Trade patterns may be a function of global production location strategies of firms, but does the ownership structure within these global production systems matter? We will argue that this structure is partly endogenous to the dynamics of international competition itself. Specifically, if intra-firm trade is the result of firm internalization strategies, then the observed rise in non-arm's length subcontracting requires a theory of externalization.

\footnotetext{
${ }^{20}$ Amsden (2001), pp. 5-6. An important exposition of the technology gap model of trade is Dosi, Pavitt and Soete (1991). For a survey of empirical studies of price versus non-price competition, see Fagerberg (1996).
} 
Firms internalize an international production process to protect rents that accrue to their firm-specific (often knowledge-based) assets. Such rents are possible only in an oligopolistic industry, in which economies of scale and market power can both foster the development of such assets and permit their continued profitability. Conversely, firms will externalize a portion of the operation if the expected cost savings exceed the expected rent accrual. This is more likely to be the case when (intermediate) product markets are competitive.

If there is competition, or if it is possible to create competitive conditions among suppliers, then the lead firm should externalize its outsourcing. If oligopoly conditions can be maintained at the level of suppliers, then it is in the lead firm's interest to retain suppliers internally. That is, firm strategy is to externalize whenever downstream markets are competitive. If externalization itself fosters downstream competition, the asymmetry of market structures along the global commodity chain can be considered endogenous to lead firms'competitive strategies.

To the extent that the asymmetry in market structures is endogenous, then by the same reasoning so is the rising incidence of externalization. Competition among suppliers is beneficial to lead firms not only because of its cost implications. It also enhances the flexibility of lead firm supply conditions. ${ }^{21}$ Lead firms can set relatively short-term subcontracts, allowing the ability to more rapidly respond to changes in final good demand conditions or changes on the supply side, on issues ranging from changes in product design, to changes in wage, exchange rate or policies in the countries with suppliers or potential suppliers.

Many management experts have remarked on the increasing tendency of firms to focus on "core competence" and to otherwise rely on arm's length outsourcing. Such a shift permits firms to focus on aspects of the process in which entry is difficult, mainly because of the skill and technology they require. Firms reduce their scope to their core competence not only for the obvious reason that this is what they are best at, but also because this is the aspect of the integrated production process that generates rents and which maximizes the possibility of retaining those rents over time. Thus, core competence is difficult to isolate from market power.

Another factor driving such externalization is policy, both in the developed and developing countries, in particular the establishment of export processing zones (EPZs) - special areas in which goods may be imported duty free and most output is for export. EPZs are most common in East Asia and Latin America and are largely concentrated in just two sectors, apparel and electronics. Electronics is considerably more capital-intensive than apparel. The degree of foreign ownership of EPZ-based firms varies across regions, and is much higher in Latin America than in East Asia. In a study of Central American EPZs, for example, Jenkins et al. (1998) find local ownership of 11 per cent of firms in Honduras and Nicaragua, about 20 per cent in Costa Rica and El Salvador, and 43 per cent in Guatemala. Another study of global patterns finds that "much of the offshore assembly processing activity is by locally owned producers rather than with foreign-owned manufacturing activities". ${ }^{22}$

\footnotetext{
${ }^{21}$ In a study of United States firm operations domestically, Harrison and Kelly (1993) find that firm outsourcing was driven more by a concern with flexibility than with cost reduction per se.

${ }^{22}$ Yeats (2001), box 2.
} 
In sum, globalized production will be increasingly coordinated externally rather than within firms if external outsourcing can create competition among suppliers, reducing costs and raising flexibility beyond what could be accomplished within the realm of internal operations. This competitive pressure on suppliers could also translate into pressure on labour costs or on labour standards. ${ }^{23}$ Such endogeneity of market structure among subcontractors can be illustrated with the concept of the global commodity chain, defined by Sturgeon (2001) as "the sequence of productive (i.e. value-added) activities leading to and supporting end use". The notion of the global commodity chain is similar to that of the column vector of an input-output table, but whereas input-output analysis emphasizes the volume of inputs per unit of output, the global commodity chain emphasizes the ownership and power structure within each link and across links in the process of commodity production, for example between lead firms and supplier firms, or between first-tier supplier firms and smaller - even home-based - subcontractors.

The lead firm typically controls the global commodity chain. Gereffi (1994) distinguishes between buyer-driven and producer-driven value chains, the distinction depending on the nature of the lead firm in the chain. A producer-driven chain is typical in industries characterized by scale economies, and driven by multinational producing firms who may outsource production but who keep R\&D and final good production within the firm. Automobiles, computers and aircraft are examples of this. Buyer-driven commodity chains occur mainly in consumer durables such as apparel, footwear and toys. In this case the global commodity chain is driven by large retailers (e.g. Wal-Mart, The Gap), that do no manufacturing themselves, but perhaps do design and marketing but subcontract the actual production of the good.

While the producer- versus consumer-led distinction may be useful for some purposes, here we will emphasize differences in market structure and thus firm power along the global commodity chain. Some hypothetical patterns of ownership and power among lead and supplier firms in the global commodity chain are summarized in figure 5.15. This is a highly simplified depiction, especially because at lower ends of the value chain there are likely to be multiple suppliers, possibly reflecting great variation in organization, from assembly-line factories to agglomerations of craft-like production, to small-scale, home-based work. The point of the stylized representation in figure 5.15 is to illustrate varieties of vertical arrangements and their implications for pricing and income distribution. Each box in the diagram represents the possibility of a different owner and a different location from the other boxes in the chain.

In figure 5.15, the four hypothetical cases illustrated are distinguished by the mark-up over costs and the share of value added at different points in the chain. Case I in the figure is labelled "vertical competition" because it depicts that of uniform mark-ups at each point in the chain; we have depicted the case of declining value added at lower points in the commodity chain, reflecting the standard view that "moving up the value chain" implies moving into higher value added production activities. Case II is titled "Pressure on subcontractors", because it shows declining mark-ups and declining value added share at lower points in the commodity chain, indicating both the possible motivation for

\footnotetext{
${ }^{23}$ Similarly, arm's length relations with suppliers reduces the buyer firm responsibility for standards in the supplying firm. A company is less likely to be held accountable for standards if the supplier is independently owned than if it is an affiliate of the buyer firm.
} 
outsourcing (less value added) and the ability to squeeze suppliers (lower mark-ups over costs). Case II describes an oligopolistic market structure at the top of the chain and a highly competitive structure at the bottom; this case most clearly reflects the asymmetry we have identified with the increasing volume of arm's length outsourcing.

Case III is that of the strong first-tier supplier, typically in a developed or newly industrialized country, for example car parts producers in Brazil, semiconductor firms in South Korea or even some apparel producers in Mexico. ${ }^{24}$ Case IV is titled "Strong middle-man", reflecting a bloated mark-up in the middle of the chain, resulting from the ability of traders to both squeeze suppliers below them and retain proprietary advantages not appropriable by demanders to whom they sell. Examples of this are the cut-flower industry, the Hong Kong apparel trade, and the cocoa and coffee trade. ${ }^{25}$

\section{Figure 5.15 Cost mark-ups and value added in the global commodity chain - Four hypothetical cases}
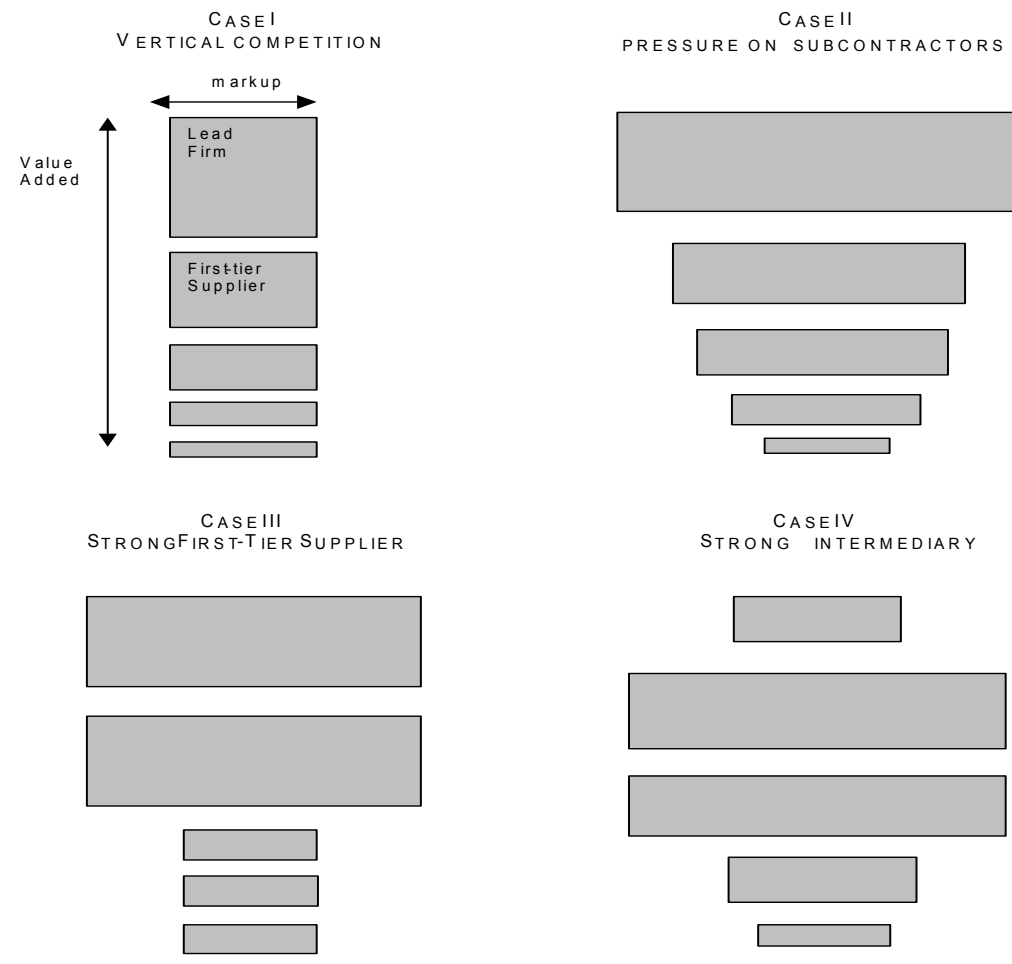

${ }^{24}$ See, for example, Bair and Gereffi (2001) and Sturgeon (2002).

${ }^{25}$ On cut flowers, see Ziegler (2001). On Hong Kong apparel trade, see Feenstra et al. (1998). Regarding coffee, see Fitter and Kaplinsky (2000), and on cocoa, see Cowell (2002). One problem with using the global commodity chain for understanding the generation of value and its distribution is that there is very little data on wages, mark-ups, and value added along particular chains. In some cases there is even difficulty tracing the chain, either because home-based production is largely unregulated and unaccountable or because the push for monitoring of labor standards by NGOs has provided an incentive for suppliers to simply hide the identity of the firms with whom they are subcontracting (Balakrishnan, 2002). A potentially fruitful area for future research is to empirically assess the incidence of each of these (and other) forms across sectors, regions and over time. Such research could help in better understanding the role of power relation in global production systems and, more important for policy purposes, the patterns of industrial upgrading and downgrading that have occurred. 


\section{Endogenous asymmetry of market structure and its consequences}

\subsection{Oligopoly competition among lead firms}

The surge of cross-border mergers and acquisitions over the past ten years indicates that a global consolidation of industry is underway. This tendency to greater concentration has been documented in more detail at the industry level. There is a prevalence of market concentration across manufacturing sectors. Firms with large market shares are exclusively developed country-owned firms. Specifically, in the face of considerable economic integration over the past 25 years, oligopoly continues to be the dominant market structure in manufacturing, agriculture and mining. While he does not provide time-series evidence, Nolan, et al. (2002) characterize the situation as a "global business revolution". This revolution, they write, "produced an unprecedented concentration of business power in large corporations headquartered in the high-income countries" (Nolan et al., 2002, p. 1). They identify a broad range of industries with high degrees of concentration as measured by market share, including commercial aircraft, automobiles, gas turbines, microprocessors, computer software, electronic games, and even consumer goods, including soft drinks, ice cream, tampons, film and cigarettes, and services such as brokerage for mergers and acquisitions and insurance. A selection of this market share evidence is presented in figure 6.16 .

Industrial concentration appears strong but some have argued that the prevalence of potential competition makes such figures less significant as indicators of market power. The evidence on firms' ability to mark-up prices over costs indicates otherwise. Despite claims that product markets have become more contestable even as oligopoly persists, a recent study shows that, with the exception of Japan, most developed country oligopoly industries exhibit mark-ups over costs that are double those in competitive sectors. The premium in the mark-up for oligopoly over competitive markets was 125 per cent in France, 47 per cent in Germany, 4 per cent in Japan, 110 per cent in the United Kingdom, and 109 per cent in the United States (see bottom line of figure 6.17). 
Figure 6.16 Market shares for various business activities

\begin{tabular}{|c|c|c|}
\hline Firm & Business activity & Market share \\
\hline \multicolumn{3}{|l|}{ Aerospace } \\
\hline Boeing & Commercial aircraft over 100 seats & 70 \\
\hline Airbus & Commercial aircraft over 100 seats & 30 \\
\hline Bombardier & $20-90$ seat aircraft & 38 \\
\hline Embraer & 20-90 seat aircraft & 36 \\
\hline Rolls-Royce & Aero-engine orders & 34 \\
\hline GE & Aero-engine orders & 53 \\
\hline Pratt \& Whitney & Aero-engine orders & 13 \\
\hline \multicolumn{3}{|c|}{$\begin{array}{l}\text { Fast-moving/branded consumer } \\
\text { goods }\end{array}$} \\
\hline Coca-Cola & Carbonated soft drinks & 51 \\
\hline Reckitt Benckiser & Dish washing powder & 38 \\
\hline Procter and Gamble & Tampons & 48 \\
\hline Gillette & Razors & 70 \\
\hline Fuji Film & Camera films & 35 \\
\hline Chupa Chups & Lollipops & 34 \\
\hline Nike & Sneakers & 36 \\
\hline Fuji & Camera film & 32 \\
\hline Kodak & Camera film & 35 \\
\hline Konika & Camera film & 11 \\
\hline \multicolumn{3}{|l|}{ IT/Electronics } \\
\hline Intel & Micro-processors & 85 \\
\hline AMD & PC micro-processors & 20 \\
\hline Microsoft & PC operating systems & 85 \\
\hline Microsoft & Word-processing applications & 90 \\
\hline Microsoft & Business desktop computer applications & 90 \\
\hline Cisco & Computer routers & 66 \\
\hline Cisco & High end routers & 80 \\
\hline Corning & Optical fibres & 50 \\
\hline Hynix & DRAMS & 17 \\
\hline Samsung Electronics & DRAMS & 29 \\
\hline Compaq & Servers & 20 \\
\hline Sony & Electronic games & 67 \\
\hline Nintendo & Electronic games & 29 \\
\hline \multicolumn{3}{|l|}{ Power equipment } \\
\hline GE & Gas turbines (1993-98) & 34 \\
\hline Siemens/Westinghouse & Gas turbines (1993-98) & 32 \\
\hline ABB/Alstom & Gas turbines (1993-98) & 21 \\
\hline Alstom & Heavy duty turbines & 15 \\
\hline \multicolumn{3}{|l|}{ Others (including services) } \\
\hline Barry Callebaut & Industrial chocolate & 33 \\
\hline Whirlpool & Major household appliances & 36 \\
\hline Shimano & Mountain bike parts & 30 \\
\hline Brita & Point of use water filters & 85 \\
\hline Goldman Sachs & Announced global M\&A & 40 \\
\hline MSDW & Announced global M\&A & 33 \\
\hline Marsh & Insurance broking & 32 \\
\hline Aon & Insurance broking & 25 \\
\hline Reuters & Financial information & 30 \\
\hline Bloomberg & Financial information & 30 \\
\hline WPP/Young and Rubicam & Advertising & 20 \\
\hline Omnicom & Advertising & 18 \\
\hline Interpublic & advertising & 18 \\
\hline
\end{tabular}


Table 6.17 Market structure and mark-ups, selected countries and sectors

\begin{tabular}{|c|c|c|c|c|c|}
\hline Industry & France & $\begin{array}{r}\text { German } \\
y\end{array}$ & Japan & UK & US \\
\hline \multicolumn{6}{|l|}{ Competitive markets } \\
\hline Food products & 1.11 & 1.12 & 1.32 & 1.2 & 1.05 \\
\hline Textiles & 1.1 & 1.15 & 1.19 & 1.03 & 1.08 \\
\hline Wearing & 1.15 & 1.11 & - & 1.03 & 1.1 \\
\hline Leather & 1.11 & 1.18 & - & 1.06 & 1.08 \\
\hline Footwear & 1.13 & - & - & 1.04 & 1.08 \\
\hline Wood products & 1.15 & 1.2 & - & 1.18 & 1.22 \\
\hline Furniture & 1.21 & 1.15 & 1.25 & 1.19 & 1.06 \\
\hline Printing and publishing & 1.24 & 1.09 & 1.1 & 1.09 & 1.19 \\
\hline Plastic products & - & - & 1.15 & - & 1.07 \\
\hline Non-metal products & 1.24 & 1.26 & 1.26 & 1.15 & 1.18 \\
\hline Metal products & 1.18 & 1.2 & 1.11 & 1.03 & 1.09 \\
\hline Chemical products & 1.19 & 1.24 & 1.26 & 1.08 & 1.26 \\
\hline Machinery and equipment & 1.12 & 1.06 & 1.09 & - & 1.06 \\
\hline Motorcycles and bicycles & - & - & - & - & 1.13 \\
\hline Professional goods & - & 1.67 & 1.22 & 1.16 & 1.09 \\
\hline Other manufacturing & - & 1.3 & 1.38 & - & 1.08 \\
\hline Average mark-up & 1.16 & 1.21 & 1.21 & 1.1 & 1.11 \\
\hline \multicolumn{6}{|l|}{ Oligopoly markets } \\
\hline Beverages & 1.68 & 1.33 & 1.26 & 1.54 & 1.56 \\
\hline Tobacco & 3.12 & 1.52 & - & 1.56 & 1.13 \\
\hline Paper and pulp & 1.13 & 1.29 & 1.2 & 1.05 & 1.03 \\
\hline Petroleum refineries & 1.19 & - & 1.04 & 1.07 & 1.11 \\
\hline Petroleum and coal products & - & 1.09 & 1.1 & 1.06 & \\
\hline Rubber products & 1.2 & - & 1.15 & - & 1.09 \\
\hline Pottery and china & 1.29 & - & 1.22 & - & 1.17 \\
\hline Glass & 1.22 & 1.23 & 1.41 & 1.06 & 1.1 \\
\hline Iron and steel & 1.16 & 1.14 & 1.19 & - & - \\
\hline Non-ferrous metals & 1.26 & - & 1.26 & 1.05 & 1.14 \\
\hline Shipbuilding and repair & - & - & 1.27 & - & - \\
\hline Other transport equipment & - & - & - & - & - \\
\hline Industrial chemicals & 1.21 & - & 1.23 & 1.06 & 1.18 \\
\hline Drugs and medicines & 1.04 & 1.45 & 1.54 & 1.16 & 1.44 \\
\hline Office and computing machinery & 1.17 & 1.58 & 1.24 & 1.47 & 1.54 \\
\hline Radio and TV & 1.11 & 1.34 & 1.13 & 1.25 & 1.4 \\
\hline Electrical apparatus & 1.25 & - & 1.05 & - & - \\
\hline Railroad equipment & 1.69 & - & - & - & - \\
\hline Motor vehicles & 1.13 & 1.15 & 1.17 & - & 1.09 \\
\hline Aircraft & 1.21 & - & - & - & - \\
\hline Average mark-ups & 1.36 & 1.31 & 1.22 & 1.21 & 1.23 \\
\hline Oligopoly premium & $125 \%$ & $47 \%$ & $4 \%$ & $110 \%$ & $109 \%$ \\
\hline
\end{tabular}

\subsection{Competition and spatial dispersion among supplier firms}

There is less evidence available on mark-ups and market structure at lower levels of the global commodity chain. Certainly most of the world's largest firms are based in developed countries. Five percent of Fortune Five Hundred Companies and 3 per cent of Financial Times 500 companies were based in low-income countries. Of the 27 developing country firms on the Financial Times 500 list, 24 were from Asia and only 3 were from 
Latin America. Of the 100 largest non-financial multinational enterprises in the world in 2000 (ranked by foreign assets), just five are from developing countries and two of these are petroleum producers (Petroleos Venezuela and Petronas of Malaysia). ${ }^{26}$ To the extent that mark-ups are associated with firm size, then we should expect lower mark-ups among developing country firms.

While size no doubt matters, it is the structure of markets and the investment strategies of firms that will determine mark-ups. At the low end of the global commodity chain, low-entry barriers are the norm. More and more countries are establishing production capability in manufacturing sectors. Most of this spatial dispersion of production is in low value added niches of markets. The pattern has often been identified in the textiles and apparel sector, and consumer electronics, but the phenomenon of more countries entering production in low value added sectors over time has been identified much more broadly across manufacturing. ${ }^{27}$ Mayer et al. (2002) measure industry concentration in terms of the number of countries involved in production. They use a standard measure of concentration, the Herfindahl-Hirschman index, substituting the number of countries for the number of firms in an industry. Figure 6.18 graphs the index for a selection of two-digit sectors. Each line on the graphs represents a three-digit sector. A decline reflects a decrease in "concentration" or, more accurately, an increase in the spatial dispersion of production in that sector. Of the 149 sectors (at the three-digit SITC level) in the data set, 119 experienced decreased concentration over the period 1980-1998. In non-manufacturing sectors, 50 of 76 experience decreased concentration. So the six three-digit sectors presented in figure 6.18 are fairly typical of patterns across manufacturing and they were in fact selected because of the variety of products they represent, including dyeing and colouring materials, to iron and steel to office machines and telecommunications equipment.

This direct evidence of greater dispersion of production across a wide variety of generally low value added manufacturing sectors is consistent with a number of recent econometric studies of competition in developing countries. Roberts and Tybout (1996) present a series of country studies that focus on entry and exit conditions, with evidence on Chile, Columbia, Mexico, Morocco and Turkey for the 1970s and 1980s. Summarizing the studies, Roberts and Tybout (1996, p. 191) write that:

[E]ntry and exit rates are substantial [...]. Despite the popular perception that entry and the associated competitive pressures are relatively limited in developing countries, these entry figures exceed the comparable figures for industrial countries.

Another study focuses on profitability and its persistence in seven developing countries (Brazil, India, Jordan, Malaysia, Mexico, Republic of Korea, and Zimbabwe) and compares that to estimates for industrialized countries. The authors find that, "Surprisingly, both short- and long-term persistence of profitability for developing countries are found to be lower than those for advanced countries." (Glen, Lee and Singh, 2002, p. 1). Finally, a study from the labour market perspective also confirms the competitive picture in developing countries. Brainard and Riker (1997) estimate the wage elasticity of labour demand across affiliates of United States multinational enterprises. A drop in the wage in a

\footnotetext{
${ }^{26}$ Fortune (2000), Financial Times (2000) and UNCTAD (2002a).

${ }^{27}$ See Gereffi (1998) on apparel, and Ng and Yeats (1999) on electronics. These two sectors are also highlighted in UNCTAD (2002b).
} 
low-wage affiliate has little effect on employment in the home operation, but a large and significant effect on employment in other low-wage affiliates of the same firm. ${ }^{28}$

\section{Figure 6.18 Concentration in selected manufacturing sectors, 1980-98}

\section{Dyeing, Tanning and Coloring Materials}

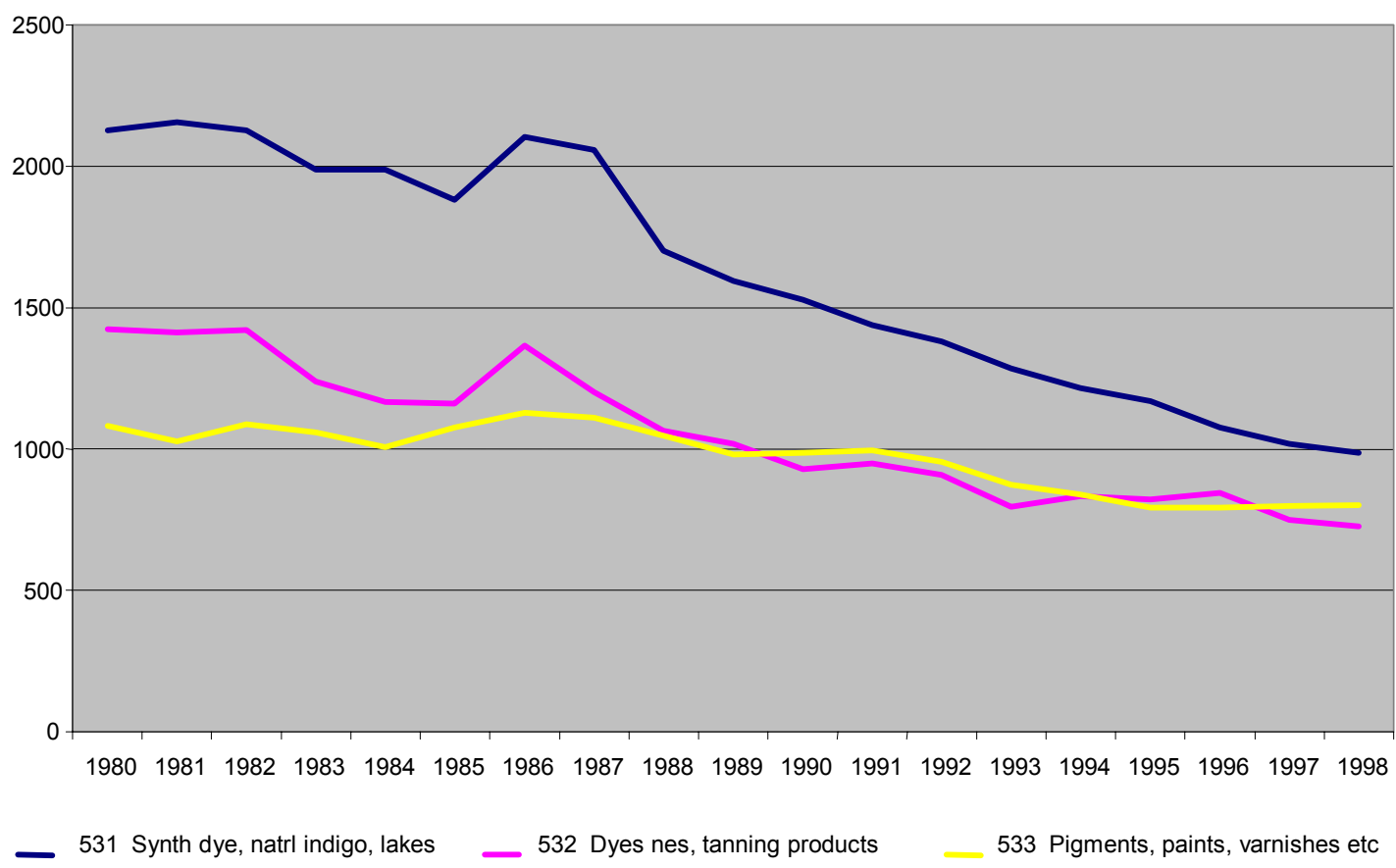

Organic Chemicals

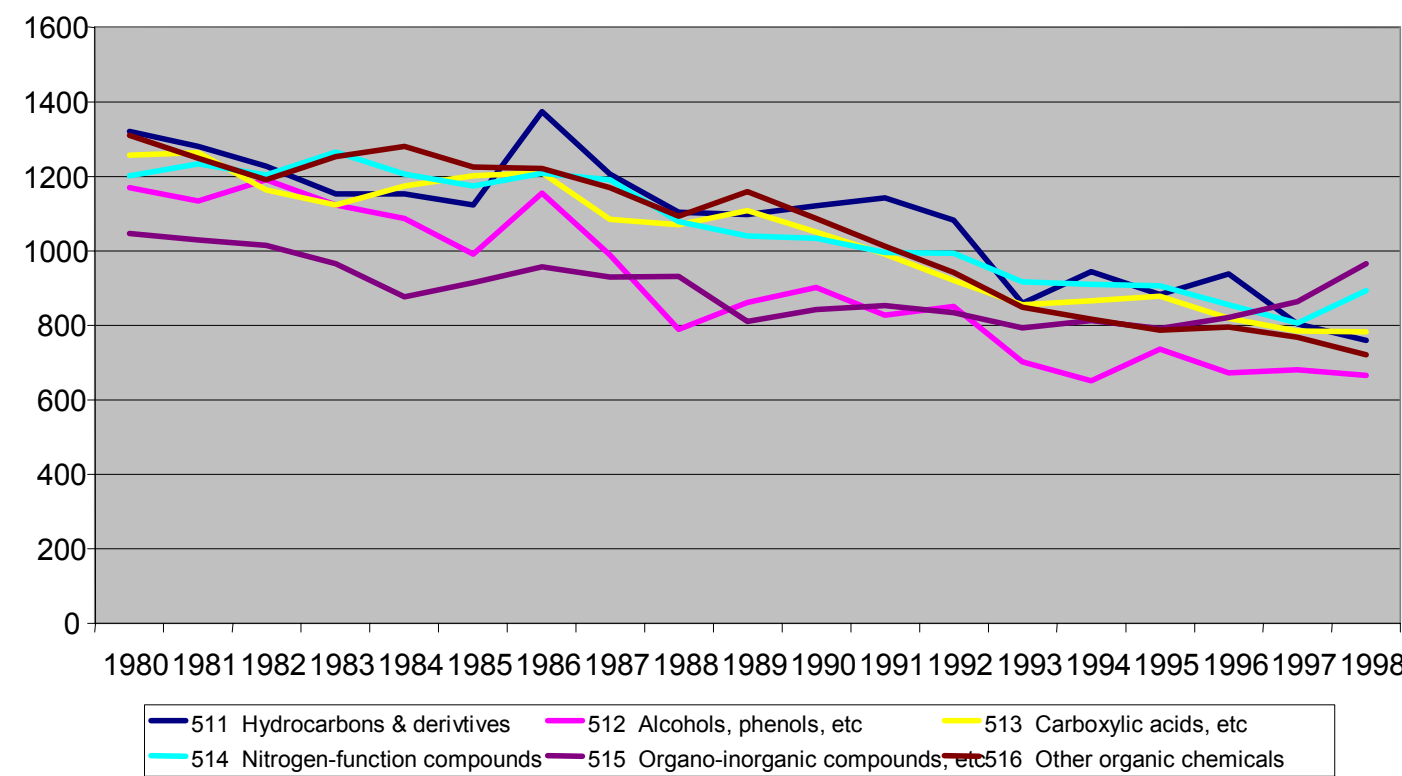

${ }^{28}$ Brainard and Riker (1997). 
Ironand Steel

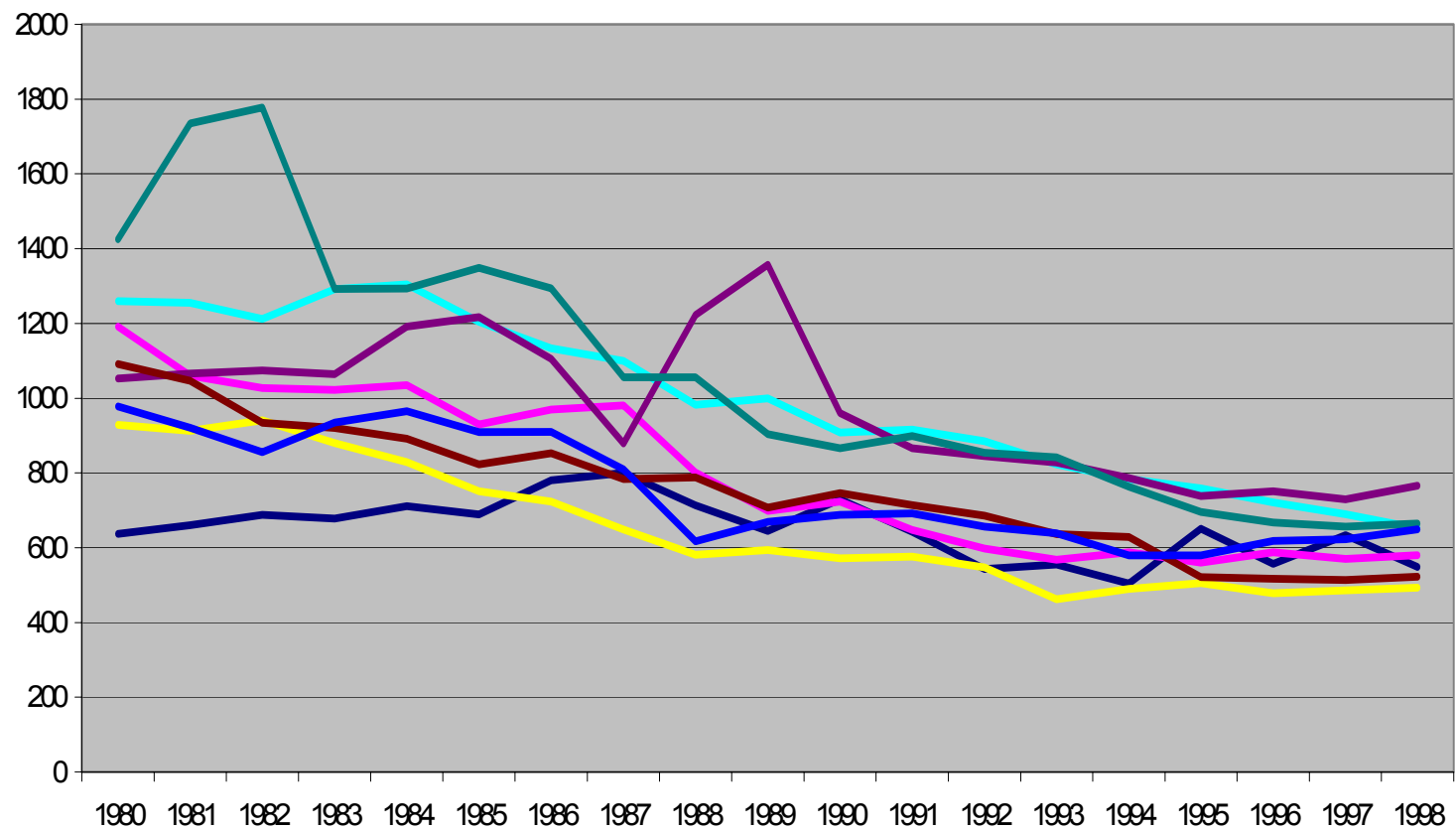

-671 Pigiron, etc - 672 Iron, sted primaryforms $\quad 673$ Iron, sted shapes, etc

674 Iron, sted univ, plate, shet -676 Railwey rails etc, iron, sted -677 Iron, sted wire, excwrod

- 678 Iron, steel tubes, pipes, etc - 679 Iron, sted castings unmorked

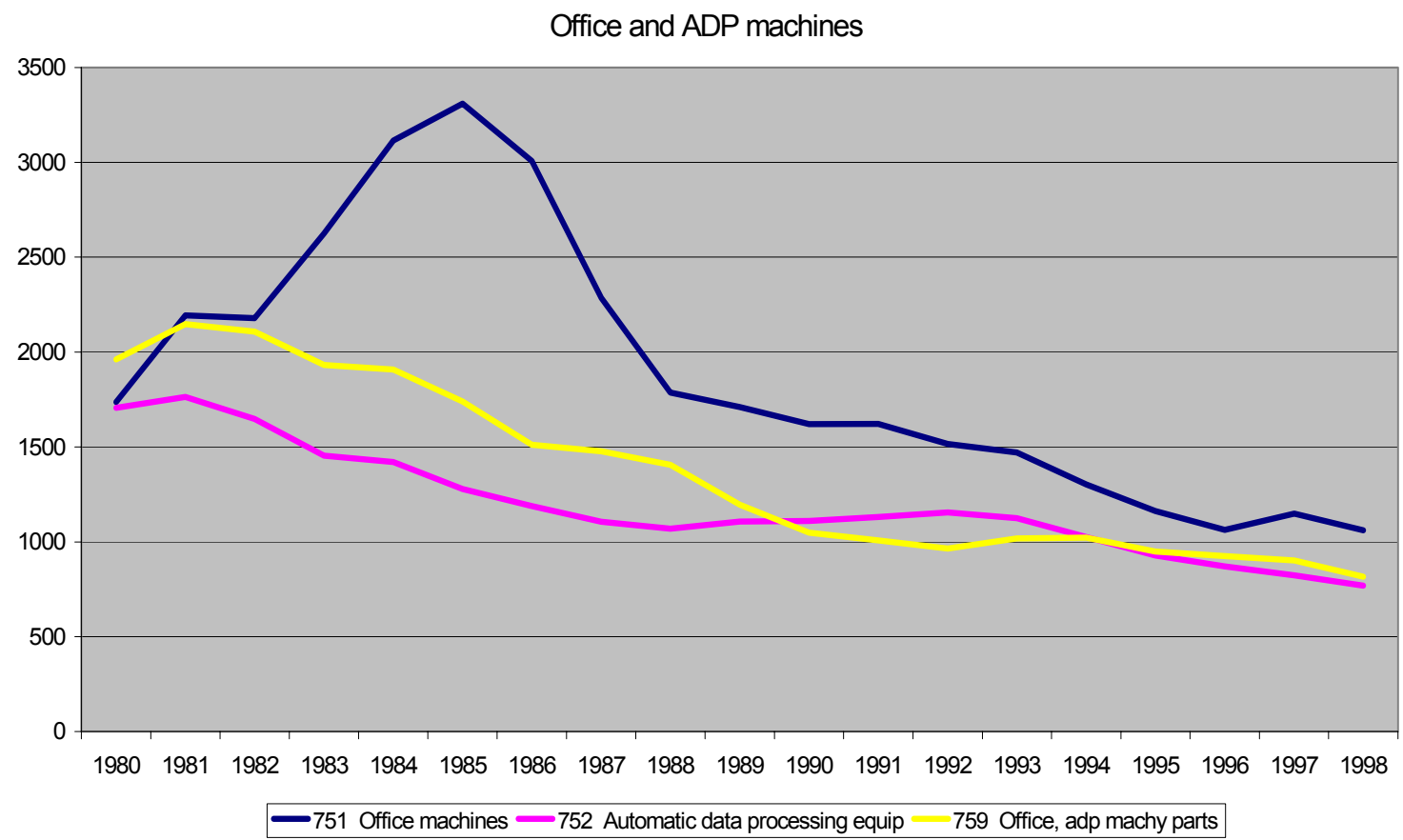


Apparel

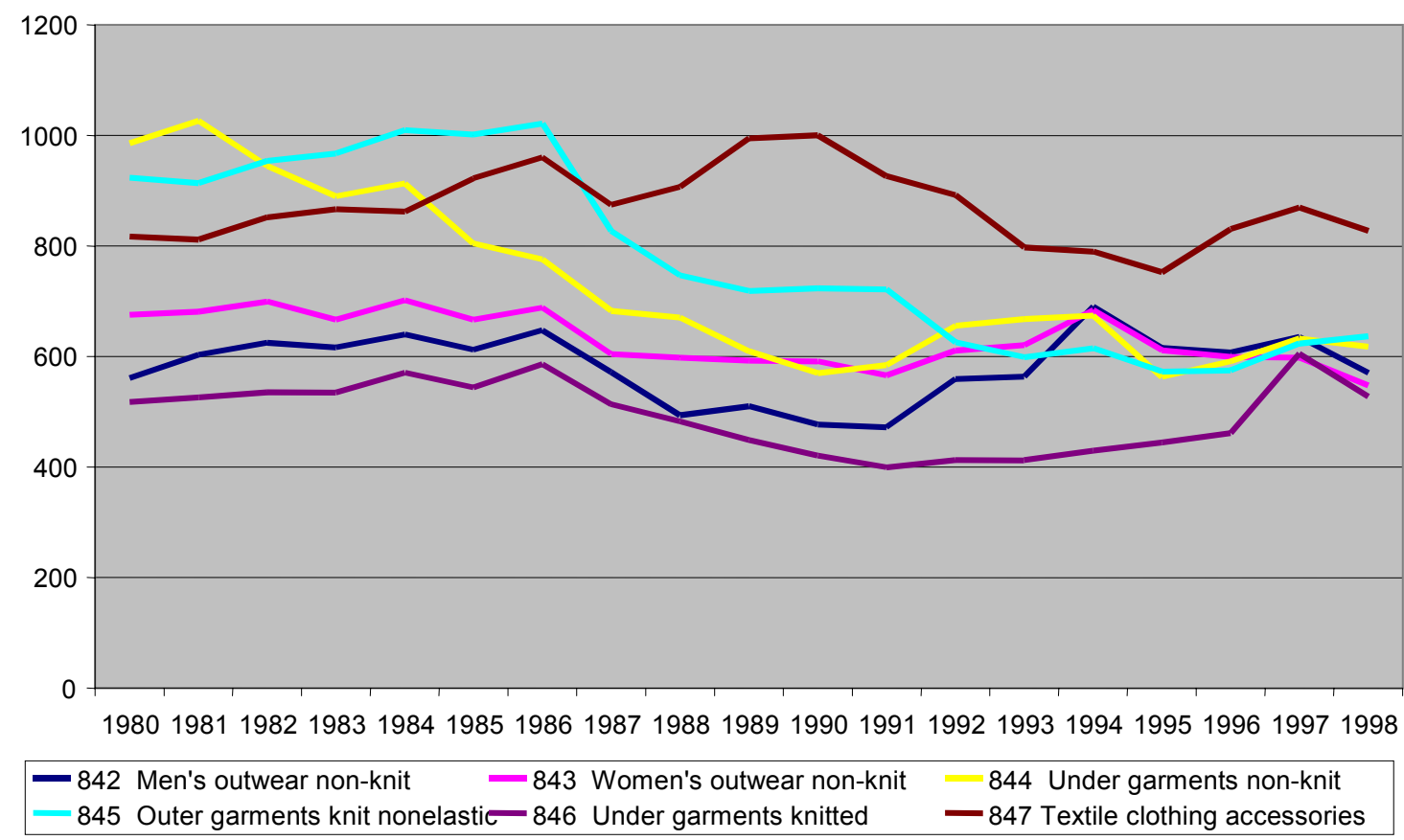

Source: $\quad$ Mayer et al. (2002).

\section{Telecommunications equipment}

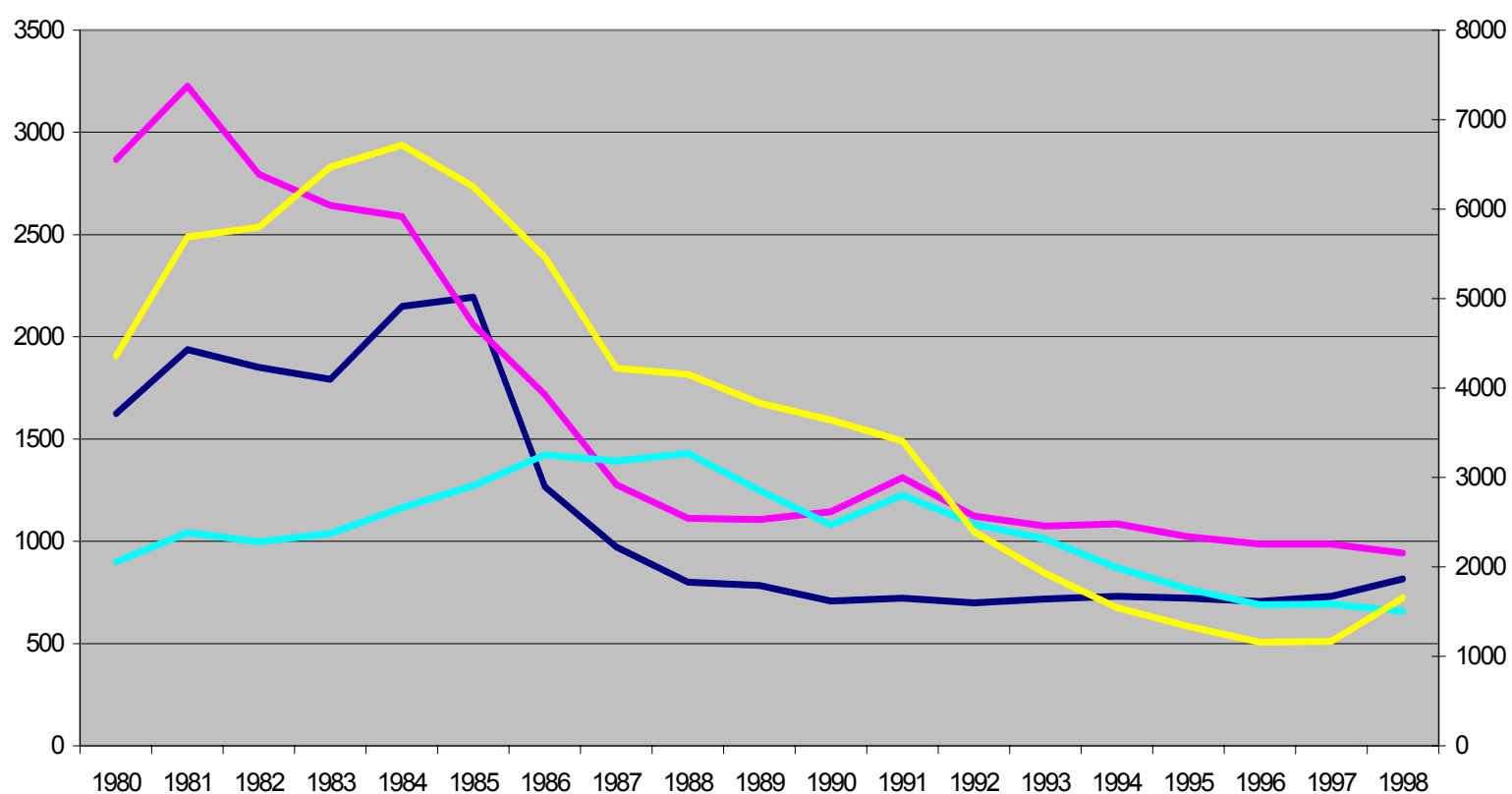

-761 Television receivers $\longrightarrow 762$ Radio-broadcast receivers $\longrightarrow 764$ Telecom equip, parts, acces 763 Sound recorders, phonographs 
In sum, there are two, seemingly incongruous, tendencies that can be discerned in the evolving structure of global industry. On one side, and despite the popular association of globalization with greater competition, there is a strong tendency towards greater concentration of industry globally. On the other side, there is evidence that more and more developing countries are entering manufacturing industries at the low end of the value chain. This constitutes the asymmetry of market structures in global commodity chains.

At least three factors make this asymmetry sustainable over time. First is the existence of entry barriers at the high end of the value chain and their absence at the low end. Entry barriers exist both for lead firms and many first-tier suppliers. At both levels of the global commodity chain, scale economies may deter entry. ${ }^{29}$ In addition to the technological issues mentioned above, brand loyalty makes market access difficult at the top of the supply chain. Even fab-less firms limit market access by innovative product design and marketing activity. In this environment, it is difficult for developing-country firms to create their own brands.

A second factor is capital mobility, which affects the low value added operations much more significantly than the high value added ones (Gereffi, 1999). Brainard and Riker's 1997 finding, mentioned above, that the elasticity of labour demand is much greater for low-wage affiliates of multinational enterprises with respect to other low-wage operations than it is between a high-wage and low-wage location, also suggests that capital mobility creates competition among low-wage locations.

A third factor is political. Tariffs have fallen most in low value-added sectors. ${ }^{30}$ This is true generally, but has also been an explicit policy goal, as seen in the tariff policies that promote low-wage offshore assembly operations, such as the 8208 Programme of the United States, European provisions evolving from the Lomé Convention, and the establishment of export processing zones in many developing countries. These programmes are highly concentrated in the garment and electronics sectors. Textiles and apparel are traditionally one of the lowest value added sectors in manufacturing, and the electronics parts and components that dominate in EPZs are at the low end of the spectrum of value added for electronics goods.

\section{Consequences for labour and capital}

\subsection{Wages, wage inequality and employment}

According to the standard theory of international trade, trade liberalization brings welfare gains to each country and globally, although not to each individual or group in every country. The widely held belief in the beneficence of free trade results from the view that "winners" in a given country can potentially compensate "losers" and still be better off than before trade liberalization. ${ }^{31}$ Specifically, the Stolper-Samuelson theorem of the factor

\footnotetext{
${ }^{29}$ See Palpaceur (2002), p. 5.

${ }^{30}$ Hanson and Harrison (1999).

${ }^{31} \mathrm{~A}$ number of observers have remarked that the potential Pareto criterion is misleading because in fact compensation almost never occurs.
} 
endowments model predicts that trade liberalization will lead to gains for each nation's relatively abundant factor of production. Recent research on trade liberalization and income distribution has focused on the fate of high-skill and low-skill labour. The model predicts that industrialized countries, since they are abundant in high-skill labour, will experience a relative rise in the wage of high-skill relative to low-skill labour as trade liberalization leads to a relative increase in the demand for skilled labour. Developing countries, abundant in low-skill labour, should see the opposite, that is, a fall in the gap between high- and low-skill labour as the relative demand for low-skill labour increases.

Economic models of trade in intermediate goods hypothesize that such trade follows the same pattern in terms of its effect on relative labour demand, and thus relative wages. ${ }^{32}$ Feenstra and Hanson (2001) argue that the effect of trade on wages is more pronounced the greater is the share of intermediate goods trade. This is because such trade affects both the labour demand in import competing sectors (in the traditional fashion) and the labour demand for users of the imported input. Thus, they write, "[t]rade in intermediate inputs can have an impact on wages and employment that is much greater than for trade in final consumer goods". ${ }^{33}$ A separate, but related, area of research is the effect of foreign direct investment on employment and wages. Theoretical models again hypothesize that capital movement by firms will alter the relative demand for labour in the same way as trade liberalization. Capital should move from where it is abundant ("the North") to where it is scarce ("the South"), leading to a rise in its return in the North and a fall in its return in the South, and thus an international equalization.

The prediction of the Stolper-Samuelson theory is consistent with the pattern of income inequality, and particularly wage inequality, observed in many industrialized countries. This has resuscitated interest in the factor endowments model of trade, and led to a debate over the relative importance of technological change versus international trade in explaining the rise in the wage of skilled workers relative to unskilled workers. Estimates of the effect of trade range from between 5 and 20 per cent of the total rise in United States wage inequality.

The prediction of Stolper-Samuelson for developing countries runs counter to the observed experience there. Most studies show that developing countries have also experienced a rise in wage inequality. A cross-country study covering Argentina, Chile, Colombia, Costa Rica, Malaysia, Mexico, Philippines, Taiwan and Uruguay, found that after netting out labour supply changes, trade liberalization was associated with a rising wage differential between skilled and unskilled workers in all cases except for the second liberalization episode in Argentina (1989-1993), when relative wages were stable. In separate studies, it was found that in Mexico the ratio of average hourly compensation between skilled and unskilled workers rose over 25 per cent between 1984 and 1990, for example in Chile between 1980 and 1990, wages of university graduates increased by 56.4 per cent over those of graduates. ${ }^{34}$

\footnotetext{
${ }^{32}$ For example, Deardorff (2001).

${ }^{33}$ Feenstra and Hanson (2001), p. 1.

${ }^{34}$ See Robbins (1996) for a survey of the cross-country evidence and original estimates. Note that this period in Argentina was also the only case in the study in which trade liberalization reduced trade openness (as measured by exports pus imports as a share of GDP). This was largely due to an overvalued exchange rate that dampened exports. Moreover, even this result is overturned when we consider a longer time period: Between 1986 and 1994 there was an increase in the return on investment in college education and a decline in the return on investment in less-than-college education. See Pessino (1995) and Amadeo (1998).
} 
What are the reasons for the failure of Stolper-Samuelson to predict the effect of trade and investment liberalization on income distribution in developing countries? In the mid-1990s, international trade economists developed the notion of "skill-enhancing trade", according to which increasing specialization in low-skill intensive sectors still constituted an increase in the demand for skills in these markets, the result mainly of greater skills required to work with more high-technology imported inputs. But skill-enhanced trade was more of an ex post rationale than a full-blown theory, and other factors are also at work.

It is hard to disentangle the apparently simultaneous forces of technical change, globalization and policy or institutional reform that has occurred over the past 25 years. A number of authors have questioned the importance of skill-biased technical change, even in the industrialized countries where it was alleged to be most evident. ${ }^{35}$ The problem is that much of the rise in wage inequality occurred before the great wave of computerization of the workplace. But few studies have considered the timing of such changes in developing countries.

A second factor is foreign direct investment. Since trade and foreign direct investment are increasingly complementary, it is perhaps not surprising that their labour market effects in developing countries appear to be mutually reinforcing. Most studies of the effect of foreign direct investment on wages find that multinational enterprises pay above-market wages, ranging from 8 per cent higher in Cameroon to 29 per cent higher in Venezuela. In every study where high and low-skill workers are studied, the wage premium (that is, the amount above the market wage) is greater for high-skilled workers. This may be due to the differential effect of foreign direct investment on labour demand. ${ }^{36}$ Slaughter (2002), for example, finds that labour demand from United States foreign direct investment in developing countries is biased toward more high-skilled labour. Non-technological factors, perhaps related to efficiency wages, are also likely in the case of multinational employment.

Feenstra and Hanson (1997) claim that it is the increase in foreign direct investment and foreign outsourcing by developed country multinational enterprises rather than trade liberalization per se that is behind the rising wage inequality in developing countries. Using regional data from Mexico, they find that in regions where foreign direct investment is concentrated, over half of the rise in the skilled labour wage share that occurred in the $1980 \mathrm{~s}$ is associated with foreign outsourcing. Thus, with foreign direct investment, production became more skill-intensive in both the high-skill abundant and low-skill abundant regions. More recent research shows that foreign outsourcing has been found to be statistically significantly associated with the rise in wages of skilled workers in the United States, Japan, Hong Kong (China), and Mexico (Feenstra and Hanson, 2001). Brainard and Riker (1997) find that wage declines in low-wage locations have no measurable effect on employment in parent multinational enterprise employment, although they do have a fairly large impact on employment in affiliates in other low-wage locations. Finally, economists have just begun to consider the indirect effects of trade and investment liberalization resulting from their effects on the bargaining power of labour. ${ }^{37}$

\footnotetext{
${ }^{35}$ See Howell, Houston and Milberg (2001) and references therein.

${ }^{36}$ See the review in Te Velde and Morrissey (2001).

${ }^{37}$ See Epstein and Burke (2001) for a review of the issues and evidence.
} 
The endogenous asymmetry of market structures provides an additional explanation, since it posits that external outsourcing will increase competitive pressure on developing country firms in global production systems. There are at least two channels through which wages are affected. One is the neoclassical channel whereby product prices affect factor prices: as suppliers are pressured to lower their prices, they will in turn reduce wages. The other is the institutional channel whereby competitive pressure on suppliers and their host countries leads to deregulation or circumvention of existing labour market regulation, and pressure on workers to accept wage declines. ${ }^{38}$ Endogenous asymmetry of market structures does not necessarily imply rising wage inequality in developing countries, although low-skill workers are typically in a weaker bargaining position than high-skill workers. However, the endogenous asymmetry of market structures does imply a divergence in factor prices internationally, contrary to the prediction of the traditional theory.

\subsection{The international flow of profits}

In addition to the wage and employment effects of globalized production is the impact on profits and the flow of profits internationally. This flow will have consequences for the balance of payments and, more importantly, for the ability of developing countries to invest and grow. Profit on foreign direct investment is either repatriated or reinvested in the host country. We have seen that increasingly global production systems are arm's length or quasi-arm's length. The growing tendency towards externalization implies that the return on external outsourcing - implied by the cost reduction it brings to the buyer firm - must exceed that on internal vertical operations. This paper argued that the asymmetry of lead and supplier market structures created the conditions for greater returns from externalization than internalization. The return on vertical foreign direct investment suggests a lower bound on cost saving from external outsourcing. And these cost savings constitute rents accruing abroad in the same sense that internal profit generation does for a multinational enterprise.

To get a crude measure of implicit profit flows from external outsourcing, we can apply the return on foreign assets to all trade in intermediate goods. As a first pass, we calculate the ex post rate of return on United States operations abroad, by dividing foreign income by the corresponding accumulated stock of foreign investment in various countries. The results are presented in figure 7.19. For the aggregate of U.S. investment abroad, this return was 9.32 per cent on a foreign capital stock of US $\$ 1.3$ trillion. ${ }^{39}$ The average return

${ }^{38}$ The Stolper-Samuleson theory used above as a benchmark assumes full employment. But of course changes in trade and investment patterns can have considerable net employment effects. Of particular concern among developed country workers is the erosion of jobs in manufacturing relative to non-manufacturing jobs, a process otherwise termed deindustrialization. To what extent has foreign trade and investment contributed to the process of deindustrialization? Kucera and Milberg (2003) find that of the 6.2 million decline in OECD manufacturing employment between 1978 and 1995, more than half can be associated with changes in the OECD trade pattern, especially trade with developing countries. They conclude, however, that what is driving this result is the drop in developing country imports from the OECD following the debt crises of the 1980s. They do not separate the effects of final goods and intermediate goods trade.

${ }^{39}$ Note that for foreign investment in the United States, the return on assets was only 3.29 per cent. This difference has been attributed to a variety of factors, including age of investment and firm concern with the United States market share. See Mataloni (2000) for a detailed study. 
on assets in developed countries was 9.1 compared to 9.82 in developing countries. When we break out the vertical from the horizontal investment, the gap widens further, at 10.96 for vertical and 8.45 for horizontal. The return on external outsourcing must exceed that on vertical foreign direct investment, implying considerable cost savings from externalization.

We do not have much time-series evidence on the return on assets in foreign investment (the data go back to 1994), so we cannot say anything about whether the return on verticalization has risen absolutely or relative to horizontal investment over time. However, we do have evidence over time generally on the growth in outsourcing and profits by sector of the United States economy. Here we find a shift in the relation between profits growth and international outsourcing by sector over time, as figure 7.20 shows. The correlation between outsourcing and the growth of profits was statistically insignificant in the period 1975-1985. In the period 1985-95, outsourcing and profits growth were positively and significantly correlated (see bottom of figure 7.20).

This evidence of a correlation between outsourcing and profits growth is consistent with a variety of studies of outsourcing both in the business and the economics literature. Frohlich and Westbrook (2001) find firm success to be more common in firms with a wider scope of supplier relations, what they term a wider "arc of integration." In sum, international outsourcing is increasingly associated with profits growth and the "return" on outsourcing is above 11 per cent. While such cost reductions (greater than 10.9 per cent) constitute a welfare gain for the United States in the same way that repatriated profits on foreign direct investment are a benefit, the rents from externalization will be shared among stockholders, employees and consumers. In theory, the degree to which the cost saving from international outsourcing is passed through to lower consumer prices will depend on domestic product market structure. Thus in industries typically considered more competitive in the developed countries, such as textiles and apparel, toys and footwear, more international outsourcing would be expected to bring lower consumer prices. In industries known for their oligopolistic structure, such as steel and automobiles, on the other hand, mark-ups would be likely to rise in the presence of cost-reducing international outsourcing. In the case of intra-firm trade, a third possibility arises: transfer pricing aimed at raising profits in subsidiary firms.

The cases of apparel and electronics have been most studied, and the price effects of outsourcing have been noted even in the popular press. A December 2002 article in the The New York Times notes that, "Even intrepid bargain hunters are shocked by the prices they are seeing in the stores this holiday season." Noting that prices in apparel and electronics have dropped for over a decade because of low-wage outsourcing, the article points out that the price pressures on producers is particularly effective this year because of the decline in demand following the 11 September terrorist attack and the excess capacity in place. In the same article, one Hong Kong based manufacturer is quoted as saying that: "Other factories, other countries are lowering their prices, so I can't keep my price." (cited in Day, 2002) 
Figure 7.19 Return on foreign assets (ROFA), United States vis-à-vis selected countries, 2000 (US\$ million)

\begin{tabular}{|c|c|c|c|c|c|c|c|c|}
\hline \multirow{2}{*}{$\begin{array}{c}\text { Average ROFA } \\
\text { Developed countries }\end{array}$} & \multicolumn{2}{|r|}{ FDI in US } & \multicolumn{4}{|c|}{ US FDI abroad } & & \\
\hline & & & 3.38 & & & 9.10 & & \\
\hline Developing countries & & & 2.04 & & & 9.82 & & \\
\hline Horizontal & & & 3.70 & & & 8.45 & & \\
\hline Vertical & & & 0.25 & & & 10.96 & & \\
\hline \multirow{2}{*}{ Countries } & \multirow{2}{*}{ FDI stocks } & \multirow{2}{*}{ FDI flows } & \multirow{2}{*}{ Income } & \multirow{2}{*}{ FDI stocks } & \multirow{2}{*}{ FDI flows } & \multirow{2}{*}{ Income } & \multicolumn{2}{|c|}{ ROFA } \\
\hline & & & & & & & in US & Abroad \\
\hline All countries & $1,163,681$ & 236,241 & 38,272 & $1,282,742.3$ & 151,174 & 119,519 & 3.29 & 9.32 \\
\hline Canada & 104,586 & 19,010 & $-1,488$ & 126,531 & 17,171 & 12,855 & -1.42 & 10.16 \\
\hline Europe & 807,273 & 193,402 & 34,769 & 672,403 & 82,595 & 59,965 & 4.31 & 8.92 \\
\hline Austria & 3,229 & 171 & 120 & 3,243 & -85 & 359 & 3.72 & 11.06 \\
\hline Belgium & 13,439 & 1,577 & 378 & 20,010 & 601 & 1,620 & 2.82 & 8.09 \\
\hline Denmark & 3,911 & 22 & -12 & 5,104 & 893 & 459 & -0.30 & 8.99 \\
\hline Finland & 7,562 & 1,869 & 186 & 1,174 & 110 & 198 & 2.46 & 16.89 \\
\hline France & 122,879 & 31,315 & 4,849 & 39,056 & 1,059 & 1,903 & 3.95 & 4.87 \\
\hline Germany & 129,908 & 21,928 & 747 & 53,615 & 6,242 & 3,966 & 0.57 & 7.40 \\
\hline Ireland & 22,227 & 2,037 & 949 & 624 & 32 & 109 & 4.27 & 17.52 \\
\hline Italy & 5,451 & 794 & 123 & 31,420 & 4,738 & 4,443 & 2.26 & 14.14 \\
\hline Netherlands & 143,174 & 29,820 & 6,886 & 119,921 & 9,088 & 12,624 & 4.81 & 10.53 \\
\hline Norway & 2,457 & -494 & -32 & 6,046 & 605 & 1,381 & -1.30 & 22.84 \\
\hline Spain & 4,433 & 2,093 & 43 & 19,300 & 2,597 & 1,341 & 0.97 & 6.95 \\
\hline Sweden & 21,560 & 3,090 & 1,455 & 16,833 & 4,993 & 931 & 6.75 & 5.53 \\
\hline Switzerland & 82,578 & 23,720 & 2,924 & 54,417 & 8,332 & 7,233 & 3.54 & 13.29 \\
\hline United Kingdom & 195,121 & 66,149 & 12,589 & 239,813 & 32,278 & 15,874 & 6.45 & 6.62 \\
\hline Other & 5,892 & 3,224 & 216 & 12,329 & 1,193 & 1,215 & 3.67 & 9.85 \\
\hline Latin America & 51,372 & 10,045 & 1,135 & 253,056 & 28,076 & 19,019 & 2.21 & 7.52 \\
\hline Brazil & 733 & -17 & 69 & 37,578 & 2,186 & 1,282 & 9.46 & 3.41 \\
\hline Mexico & 5,750 & 2,152 & -321 & 40,796 & 5,640 & 4,409 & -5.58 & 10.81 \\
\hline Panama & 4,400 & -418 & 626 & 29,252 & 1,414 & 1,106 & 14.23 & 3.78 \\
\hline Venezuela & 1,820 & 454 & 49 & 8,786 & 2,059 & 948 & 2.69 & 10.79 \\
\hline Other & 1,873 & 635 & 115 & 769 & -45 & 24 & 6.16 & 3.12 \\
\hline Africa & 2,460 & 494 & -84 & 14,637 & 816 & 2,205 & -3.43 & 15.06 \\
\hline South Africa & 1,107 & 381 & -22 & 3,068 & 453 & 152 & -1.99 & 4.94 \\
\hline Other & 1,353 & 113 & -62 & 7,719 & -3 & 966 & -4.61 & 12.52 \\
\hline Middle East & 5,530 & 786 & 242 & 11,481 & 970 & 1,583 & 4.38 & 13.79 \\
\hline Israel & 2,684 & 357 & 53 & 3,813 & 652 & 241 & 1.96 & 6.31 \\
\hline Saudi Arabia & 945 & -325 & 0 & 4,085 & -77 & 223.7 & 0.00 & 5.47 \\
\hline United Arab Emirates & 18 & -21 & 0 & 757 & 63 & 205 & 0.00 & 27.08 \\
\hline Other & 71 & 2 & 34 & 2,825 & 332 & 913 & 47.89 & 32.33 \\
\hline Asia and Pacific & 192,460 & 12,504 & 3,699 & 202,044 & 21,412 & 23,688 & 1.92 & 11.72 \\
\hline Australia & 19,935 & 4,602 & 266 & 34,716 & 1,747 & 2,583 & 1.34 & 7.44 \\
\hline Hong Kong & 1,327 & 138 & 60 & 25,901 & 4,075 & 4,144 & 4.52 & 16.00 \\
\hline Japan & 158,793 & 5,926 & 3,333 & 59,979 & 7,067 & 6,079 & 2.10 & 10.14 \\
\hline Korea, Republic of & 3,033 & 463 & 56 & 8,632 & 1,595 & 1,045 & 1.85 & 12.11 \\
\hline Malaysia & 61 & -40 & -21 & 6,718 & 161 & 1,307 & -34.78 & 19.46 \\
\hline New Zealand & 425 & 81 & 29 & 4,079 & -132 & 277 & 6.82 & 6.80 \\
\hline Philippines & 51 & -27 & 5 & 2,881 & -88 & 416 & 9.80 & 14.45 \\
\hline Singapore & 5,206 & 1,491 & 69 & 24,502 & 3,235 & 2,823 & 1.33 & 11.52 \\
\hline Taiwan & 2,901 & -200 & -111 & 7,715 & 923 & 1,169 & -3.83 & 15.15 \\
\hline Other & 728 & 70 & 12 & 1,108 & -9 & 84 & 1.65 & 7.58 \\
\hline
\end{tabular}

Source: US Department of Commerce (2002).

Note: $\quad$ FDI stocks, flows and income are calculated as 1999-2001 average. Horizontal group consists of all of the developed countries and Brazil, but without Canada and Ireland. Vertical group consists of developing countries without Brazil but with Canada and Ireland added. 
The flow of profits and rents to developed-country firms that result from asymmetric market structure constitutes a loss of capital for investment in developing countries and a drain on the balance of payments. Developing countries have successfully shifted out of commodity exports and into the export of manufactured goods. Still, most studies find that the terms of trade for developing countries has not improved and may have even deteriorated further over the past 20 years. ${ }^{40}$ Once again, the nature of global production systems can explain this. Developing countries have specialized in low value-added products and parts, partly because of their skills and partly because of barriers to entry in the higher value added segments. Moreover, competition is intense among producers of these goods, generating enormous excess capacity globally, which places even more downward pressure on prices.

Figure 7.20 Growth in outsourcing and profits by sector: United States, 1975-95, percentage of change

\begin{tabular}{|c|c|c|c|c|c|c|}
\hline \multirow[t]{2}{*}{ Industry } & & \multicolumn{3}{|c|}{$1975-1985$} & \multicolumn{2}{|c|}{ 1985-1995 } \\
\hline & & Profits & Out & cing & Profits & Outsourcing \\
\hline Food and kindred products & & & 43. & 25.4 & 246.0 & 16.6 \\
\hline Tobacco products & & & 3.1 & 8.3 & -65.0 & 34.4 \\
\hline Textiles mill products & & & 0.8 & 80.9 & 46.5 & 34.2 \\
\hline Apparel and other textiles & & & 3.8 & 82.7 & 58.5 & 39.7 \\
\hline Lumber and wood products & & & 2.9 & 59.1 & 102.6 & 21.4 \\
\hline Furniture and fixtures & & & & 47.1 & 76.3 & 8.4 \\
\hline Paper and allied products & & & 4.2 & 22.1 & 98.5 & 23.4 \\
\hline Printing and publishing & & & 2.0 & 11.7 & 24.0 & 19.2 \\
\hline Chemical and allied products & & & 8.7 & 49.5 & 278.3 & 41.8 \\
\hline Petroleum and coal products & & & 6.8 & 0.3 & -60.3 & -21.7 \\
\hline Rubber and miscellaneous products & & & 0.2 & 43.3 & 91.7 & 34.0 \\
\hline Leather and leather products & & & 4.6 & 179.9 & -35.7 & 30.1 \\
\hline Stone, clay and glass products & & & 1.1 & 68.5 & 59.7 & 31.5 \\
\hline Primary metal products & & & & 86.1 & -503.6 & 15.3 \\
\hline Fabricated metal products & & & 5.3 & 63.4 & 220.3 & 11.6 \\
\hline Industrial machinery and equipment & & & 7.4 & 73.9 & 533.8 & 52.5 \\
\hline Electronic and other electronic equip. & & & 3.9 & 50.4 & 1002.1 & 72.9 \\
\hline Transportation equipment & & & & 66.6 & -61.2 & 47.3 \\
\hline Instruments and related products & & & 6.7 & 42.1 & 241.8 & 17.3 \\
\hline Miscellaneous manufacturing & & & 4.0 & 87.0 & 279.4 & 15.9 \\
\hline Total manufacturing & & & 3.9 & 53.0 & 85.7 & 32.0 \\
\hline Wholesale trade & & & 3.1 & & 13.2 & \\
\hline Retail trade & & & 3.8 & & 60.9 & \\
\hline Total corporate profits & & & 6.5 & & 115.1 & \\
\hline & Addendum: & $1975-85$ & $1985-95$ & Total & & \\
\hline & Corr.coeff & -0.194 & 0.539 & 0.012 & & \\
\hline & Two-tailed & $5 \mathrm{E}-05$ & 0.10 & 0.66 & & \\
\hline
\end{tabular}

Sources: Campa and Goldberg (1997), BEA (2002).

40 See UNCTAD (2002) for a review of recent evidence. Kaplinsky's (1993) study, "Export Processing Zones in the Dominican Republic", provides a clear example of how the switch to manufacturers can fail to stem the decline in the terms of trade. 
In sum, many developing countries, having successfully followed the strategy of moving away from a reliance on the export of commodities and natural resources and into the export of manufacturers, have found themselves in a modern-day Prebisch-Singer trap. ${ }^{41}$ With the change in the structure of international production and trade, the promotion of manufacturing has not been sufficient to improve the barter or factoral terms of trade. The rents earned by developed country oligopoly firms could, under a different constellation of market structure, be redistributed to developing countries, boosting their ability to invest and grow. In the final section, this paper considers some policies that might improve developing country prospects within the system of global production.

\section{Policy implications of global production systems}

\subsection{Industrial policy}

The distributional consequences of globalized production discussed in the previous section are static effects. However, it is the dynamics of industrialization and economic development that are the focus of governments and international policy-makers. Because of the globalization of production, industrialization today is different from the final goods, export-led process of just 20 years ago. Now the issue facing firms and governments is less that of finding new, more capital-intensive goods to sell to consumers in foreign countries. Instead, it seems to require the moving up through the chain of production of a particular commodity or set of commodities, so-called "industrial upgrading" into higher value added activities. This involves fitting into existing corporate strategies and in the confines of a broadly liberal international trade and investment environment or, as Gary Gereffi (2002) writes, "establishing close linkages with a diverse array of lead firms".

Industrial upgrading requires productive reinvestment of profits - the establishment of a nexus between profits and investment. ${ }^{42}$ This requires: (a) the market conditions to generate such profits in the first place; and (b) the institutions and regulations that induce the investment of these profits into productive channels. Regarding the first of these, we have seen that oligopoly firms are by definition more able to generate the necessary rents compared to competitive firms. Market demand is also crucial, as firms typically learn not just by "doing" but by selling. ${ }^{43}$ Regarding institutions and regulations, there are two levels. First is the protection of rents, through clearly defined property rights and a rule of law to enforce these rights. The second level is the ability to channel profit income into productive investment. These conditions are necessary regardless of whether the rents are generated by private or public enterprise.

Added to these apparent requirements are the structural obstacles to upgrading, closely related to the persistence of the asymmetry of market structure discussed above. Moving into higher value added may be difficult because of barriers to entry. For one, many studies show that there are limits to the international shifting of multinational enterprise

\footnotetext{
${ }^{41}$ See Bacha (1978) for a formalized restatement.

${ }^{42}$ This terminology is borrowed from Akyuz and Gore (1996).

${ }^{43}$ This point is emphasized by Porter (1990).
} 
operations. Such high value-added functions as financial management, R\&D, product design and even marketing are maintained in the parent country. ${ }^{44}$ Second, global production networks are driven and in many cases designed by lead firms, with the focus being the profitability and flexibility of the lead firm. The profitability or even efficiency of the supplier is not necessarily a consideration in the construction of the global production network. ${ }^{45}$ Third, industrial upgrading requires capital investment that is usually generated from oligopoly profits, not the competitive conditions that increasingly characterize supplier markets, as we saw above. Finally, excessive protection from competition can foster inefficiency and unproductive rent seeking.

Despite these obstacles, a number of countries have achieved widespread industrial upgrading, with the Republic of Korea and other East-Asian newly industrialized countries the most prominent examples. Significant pockets of upgrading have also occurred in Latin America, especially Argentina, Brazil, Chile, and Mexico. In most cases, the effort was underpinned by an industrial policy that, building on prior industrial experience, selectively targeted and subsidized certain sectors and activities, building a base of technology, labour skills and management that led to a slow climb up the global commodity chain. In the case of the Republic of Korea, for example, industrial policy included export subsidies, import and foreign investment controls, production targets, lowinterest credit and technical support, in order to generate the long-run efficiency defined above. ${ }^{46}$ This was supplemented by a growing educational system that raised the average skill-level of the workforce.

The common theme behind the industrial policy to firms was what Amsden (2001) calls "reciprocal control", according to which aid to firms was contingent on firm performance, be it in terms of output, production or exports. Because industrial upgrading (and international competitiveness generally) requires unique knowledge-based assets, successful industrialization has required state intervention where free and competitive markets are inadequate. Enforcement of such a regime of state-industry relations requires a particular commitment to development on the part of the State, and the reciprocity in "reciprocal control" involves an assurance to the private sector that the State will effectively deliver its developmentalist channelling of the social surplus. Evans (1995) characterizes such interventionist but independent state action as "embedded autonomy", and finds it particularly important in cases where countries developed knowledge-based assets, such as the software industry in India, the semiconductor industry in the Republic of Korea, and the computer sector in Brazil.

Amsden identifies aspects of reciprocal control in all successful late industrializing countries, from Japan and the Republic of Korea to Argentina, Brazil, Chile, China, India, Malaysia, Taiwan, Thailand, Turkey and Mexico. Despite these successes with reciprocal control and industrial policy, the industrial upgrading model is a difficult and risky path. Mexico, for all its links to multinational enterprises and to the United States market through geographic proximity and preferential trading relations under the North American Free Trade Agreement (NAFTA), have achieved only minimal gains in terms of real wages and economic growth. After the transition to capitalism, a number of Eastern European countries, for all their skill accumulation and proximity to the rich European Union market,

\footnotetext{
${ }^{44}$ UNCTAD (1993), Doremus et al. (1998).

${ }^{45}$ Semmlinger (1991).

${ }^{46}$ See Amsden (1989).
} 
saw their presence across commodity chains reduced to the low end. ${ }^{47}$ Global integration, for which there is really no viable alternative, thus brings a risk of industrial "downgrading".

\subsection{Policies to attract foreign direct investment}

In the 1990s, foreign direct investment came increasingly to be viewed as the panacea for economic development ills, providing a non-volatile source of capital that requires neither a fixed interest payment nor a repayment of principal at a specified date. We saw above (figure 2.4) that developing countries have relied increasingly on foreign direct investment to meet their need for foreign capital, and the developing-country share of world foreign direct investment has grown (if slightly) over the past ten years. In terms of their direct effect on host developing countries, multinational enterprises have been found to pay above-market wages, and to demand relatively more skilled labour than unskilled labour. Employment by affiliates of multinational enterprises operating in developing countries has risen steadily since 1990 .

These promising figures veil a more mixed picture at the level of specific countries. First of all, foreign direct investment to developing countries is highly skewed. Most of it (23 per cent, 34 per cent if we include Hong Kong) has gone to a single country - China and the remainder has gone mostly to a small handful of other countries, most significantly Brazil and Mexico. Figure 8.21 shows the amount and share of developing-country foreign direct investment going to the top recipients of such flows. The skewed distribution implies that most countries have not received much foreign direct investment at all. Moreover, foreign direct investment continues to be a small percentage of developing country gross fixed capital formation, ranging from 8 per cent in Africa and 12 per cent in Asia to just over 20 per cent in Latin America and Central Asia (figure 8.22). The latter figures are impressive, However, almost half (42 per cent) of foreign direct investment in Latin America is "brownfield" (that is, the result of international mergers and acquisitions) rather than "greenfield" investment (see figure 8.23). Overall, it is more likely that inward foreign direct investment lags rather than leads indicators of long-term economic growth. Certainly this was the experience of the most successful cases of industrialization in the last part of the twentieth century in East Asia. ${ }^{48}$

These points about the relation between foreign direct investment and economic development are well known. In fact the debate over foreign direct investment and economic development has largely shifted away from discussion of the static issues of effective demand and employment and towards issues of externalities, largely understood as the indirect effects of multinational enterprise activity on labour through their effects on host country competition and productivity. Foreign investment may enhance or diminish the degree of competition in host country markets. Agosin and Mayer (2000) find that over the period 1970-96, foreign direct investment tended to crowd out or have no effect on domestic investment in Latin America and Africa and to crowd in or have no effect on investment in East Asia. Braunstein and Epstein (2002) find crowding out in the case of foreign direct investment into China.

\footnotetext{
${ }^{47}$ This was the case of the garment sector in Romania, for example.

${ }^{48}$ See Amsden (1994).
} 
Figure 8.21 Leading developing country recipients of foreign direct investment, 1999-2001

\begin{tabular}{l|rr}
\hline \multicolumn{1}{c|}{ Country } & $\begin{array}{r}\text { FDI inflows (1999-20001 } \\
\text { average in US\$ million) }\end{array}$ & $\begin{array}{r}\text { Share (\%) in FDI } \\
\text { to developing countries }\end{array}$ \\
\hline China & $42,645.67$ & 17.1 \\
Hong Kong, China & $36,456.00$ & 14.6 \\
Brazil & $27,938.00$ & 11.2 \\
Mexico & $17,323.67$ & 7.0 \\
Argentina & $12,822.33$ & 5.2 \\
Bermuda & $10,103.00$ & 4.1 \\
Singapore & $8,606.33$ & 3.5 \\
Poland & $8,480.67$ & 3.4 \\
Republic of Korea & $7,271.33$ & 2.9 \\
Chile & $6,134.33$ & 2.5 \\
\hline
\end{tabular}

Source: UNCTAD (2002a).

Figure 8.22 Foreign direct investment as a share of gross fixed capital foration by country / region, 1986-2000

\begin{tabular}{|c|c|c|c|c|c|c|c|c|c|c|}
\hline & \multicolumn{10}{|c|}{ Annual average } \\
\hline Country / Region & 1986-1991 & 1992 & 1993 & 1994 & 1995 & 1996 & 1997 & 1998 & 1999 & 2000 \\
\hline Developed economies & 3.5 & 2.6 & 3 & 2.8 & 3.9 & 3.6 & 6 & 10.7 & 17.4 & 25 \\
\hline European Union & 5.7 & 5.5 & 6.2 & 5.2 & 7.3 & 5.8 & 8.1 & 15.7 & 28.5 & 50.1 \\
\hline Other Western Europe & 4.3 & 2.5 & 3.9 & 8.1 & 6.2 & 8.2 & 11.2 & 13.8 & 21.6 & 27.8 \\
\hline United States & 6.5 & 2.4 & 5.1 & 4.7 & 5.8 & 7 & 7.8 & 11.9 & 18 & 17.5 \\
\hline Developing economies & 3.4 & 4.2 & 6.1 & 7.6 & 7.4 & 8.7 & 11.1 & 11.4 & 13.4 & 13.4 \\
\hline Africa & 3.9 & 5.2 & 6.1 & 9.5 & 7.9 & 7.3 & 10.0 & 8.3 & 11.9 & 8.1 \\
\hline Latin America and & 5.3 & 7.6 & 6.4 & 8.9 & 9.8 & 12.8 & 16.6 & 17.1 & 25.9 & 20.7 \\
\hline Asia & 2.8 & 3.2 & 6.0 & 7.0 & 6.6 & 7.4 & 9.2 & 9.5 & 9.6 & 11.6 \\
\hline West Asia & 0.8 & 0.6 & 2.8 & 1.2 & -0.6 & 0.2 & 3.3 & 3.6 & 0.2 & 0.3 \\
\hline Central Asia & $\ldots$ & & $\ldots$ & $\ldots$ & $\ldots$ & $\ldots$ & 39.7 & 32.2 & 29.2 & 22.9 \\
\hline South, East and South- & 3.6 & 4.5 & 6.5 & 7.9 & 7.5 & 8.3 & 10 & 10.5 & 11.5 & 14 \\
\hline Pacific & 20.2 & 38.2 & 12.6 & 9.9 & 47.9 & 15.6 & 10.6 & 29.6 & 28.9 & 9.1 \\
\hline Central and Eastern Europe & 0.1 & 1.1 & 7.4 & 4.7 & 10.2 & 7.5 & 9.7 & 13.7 & 18.6 & 18.2 \\
\hline World & 3.6 & 3.3 & 4.4 & 4.5 & 5.6 & 5.6 & 7.4 & 11.0 & 16.5 & 220 \\
\hline
\end{tabular}

Source: $\quad$ UNCTAD (1998), annex table B.5 for 1986-1996, UNCTAD (2002a), annex table B.5 for 1997-2000. 
Figure 8.23 Mergers and acquisitions as share (\%) of foreign direct investment by country Iregion, 1990-2001

\begin{tabular}{|l|rrrrrrrr}
\hline Country / Region / Economy & 1990 & 1995 & 1996 & 1997 & 1998 & 1999 & $\mathbf{2 0 0 0}$ & $\mathbf{2 0 0 1}$ \\
\hline Developed economies & 81.6 & 80.6 & 85.3 & 86.6 & 91.5 & 81.1 & 86.0 & 98.6 \\
European Union & 68.9 & 65.7 & 74.2 & 89.6 & 71.6 & 73.2 & 72.5 & 65.9 \\
\hline Other Western Europe & 79.5 & 103.8 & 120.6 & 69.8 & 52.2 & 69.4 & 102.5 & 121.0 \\
\hline United States & 114.1 & 92.3 & 87.7 & 74.8 & 108.4 & 88.9 & 107.8 & 148.6 \\
Developing economies & 42.73 & 14.66 & 23.40 & 35.07 & 44.06 & 32.87 & 29.68 & 41.90 \\
Africa & 19.53 & 14.63 & 30.93 & 40.45 & 28.90 & 24.10 & 36.80 & 90.44 \\
\hline Latin America and Caribbean & 111.79 & 27.98 & 38.80 & 55.32 & 77.76 & 38.39 & 47.40 & 41.98 \\
\hline Asia & 16.80 & 9.24 & 14.32 & 20.12 & 16.75 & 28.06 & 16.59 & 33.75 \\
$\quad$ West Asia & 5.28 & 7400 & 13.91 & 6.52 & 1.22 & 103.40 & 140.99 & 32.01 \\
$\quad$ Central Asia & $n a$ & 30.32 & 124.36 & 60.87 & 5.52 & 2.96 & 5.65 & 0.42 \\
$\quad$ South, East and South-East Asia & 17.91 & 8.51 & 20.45 & 35.67 & 37.27 & 47.65 & 23.36 & 69.69 \\
$\quad$ Pacific & $n a$ & 9.42 & 6.94 & 171.33 & 14.80 & 48.03 & 5.68 & $\mathrm{Na}$ \\
\hline Central and Eastern Europe & 44.60 & 41.12 & 26.94 & 29.46 & 22.63 & 40.84 & 64.55 & 42.67 \\
World & 74.26 & 56.46 & 58.79 & 63.76 & 76.56 & 70.39 & 76.67 & 80.79 \\
\hline
\end{tabular}

Source: UNCTAD (2002a). Note: Data for United States FDI 1990-1998 are from IMF (2001).

Indirect productivity effects of foreign direct investment are said to occur through technological spillovers. If technology spillovers of TNC activity raise domestic productivity in other firms or sectors, then both wages and possibly employment will be positively influenced. But here too the evidence is mixed at best. Most studies have not found measurable effects of new technologies on domestic firms' ability to upgrade and raise productivity. ${ }^{49}$

The establishment of export processing zones has become an important policy for the attraction of foreign direct investment. There is an ongoing theoretical debate over the merits of EPZs for countries that maintain them. ${ }^{50}$ In practice, EPZs are concentrated in only two sectors, textiles and apparel, and electronics, the latter being considerably more capital-intensive than the former. They are most prominent in East Asia and Latin America, and in both cases they employ mainly young women. Wages in EPZs are found to be around the same as in the rest of the manufacturing sector, although there is variation by country. In sum, the direct effect of EPZs is positive for employment and the trade balance. They are also in some cases a significant draw for foreign investors. In Costa Rica, for example, over half of inward foreign direct investment is located in EPZs.

The effect of EPZs on economic development depends on the backward linkages they create, that is, the connections with the rest of the nation's economy. These linkages are often measured by the share of locally produced inputs they use. Here the East-Asian and Latin American experiences have been quite different. In East Asia, the use of domestically produced inputs typically has grown after an initial period. In Latin America, this has not been the case. EPZs in Latin America have produced a greater share of total exports than has been the case in East Asia, but this may also reflect the greater success in diversification and upgrading that occurred in East Asia. The main success stories in the promotion of backward linkages using EPZs are the Ireland, Taiwan (China) and the Republic of Korea. These countries used policy to link EPZ activity to domestic producers

\footnotetext{
${ }^{49}$ See Gorg and Greenaway (2002) and Rodrik (1999).

${ }^{50}$ See Chaudhury and Adhikari (1993), for a review.
} 
in an effort to create a broader base of strength in exports. These are the exceptions however. In Central America, a region where EPZs are in wide use EPZs, "have been seen mostly as mechanisms to create employment and generate foreign exchange, but not as drivers of an export-led growth strategy. Consequently, the creation of linkages has not been a priority in the policy agenda of most of the region". ${ }^{51}$

In sum, foreign direct investment has not tended to spur economic development. In most cases, even for developing countries, foreign direct investment is a lagging phenomenon, growing most when a strong domestic market exists or when infrastructure and political stability are in place to guarantee adequate returns. Moreover, to capture the potential positive technological spillovers from foreign direct investment requires the attainment of a certain level of absorptive capacity, reflected in infrastructure and human capital. Second, incentives to attract foreign direct investment - including tax giveaways, tariff reductions, promises of lax labour or environmental standards - have generally not been very successful in attracting foreign direct investment (Wheeler and Mody, 1992; Kucera, 2002). A detailed study of the incentives granted by Costa Rica to the semiconductor producer Intel finds that these were probably not necessary to attract the investment in the first place, and certainly have diminished the host country benefits from the investment. ${ }^{52}$ Moreover, foreign direct investment concentrated in EPZs has not generated significant backward linkages.

As with many aspects of globalization, inward foreign direct investment is not "good" or "bad" for developing countries in an a priori sense. Its effects vary over time, country and industry. Foreign direct investment should be understood as a source of capital, technology, and market access that must be managed to be most effective. While domestic protection for multinational enterprise affiliates will promote anti-competitive outcomes, at the same time, competition to attract multinational enterprises by offering tax concessions and lax labour standards work against the strategy of industrial upgrading.

Policy-makers must realize that the attraction of foreign direct investment is not an end in itself. If sustainable economic growth is the goal, then attracting foreign direct investment should not be the centrepiece of most countries' development strategies, if not for a few exceptions. According to Rodrik (1999, p. 147):

Gearing economic policy toward performance in the external sectors of the economy, at the expense of other objectives, amounts to mixing up the ends and the means of economic policy. Furthermore, there is nothing more conducive to trade and DFI than strong economic growth itself. Foreign investors care little about Botswana's huge public sector, and neither are they much deterred by Chinese-style socialism. Policies that are successful in igniting growth are also likely to pay off in terms of international competitiveness.

\footnotetext{
${ }^{51}$ Jenkins et al. (1998), p. 45.

${ }^{52}$ Hanson (2000).
} 


\subsection{Competition policy}

Industrial upgrading is a new paradigm of industrialization. Its attainment requires not just overcoming the asymmetry of market structure in global production systems, but also the attainment of dynamic efficiency, that is, the maximization of long-run productivity growth. This is different from static or "allocative" efficiency, a condition whereby productive resources move to where the returns are greatest and sovereign consumers demand goods at their lowest possible prices. Monopoly competition creates a deviation from this welfare optimum, often resulting in less output of a good and at a higher price than would occur under competitive conditions. Competition policy is aimed at limiting monopoly in order to encourage competition and its beneficial welfare effects. Any country may unilaterally adopt a domestic competition policy. And most countries have done so. Today there are more than 90 countries with competition laws. Still, about onethird of World Trade Organization (WTO) members currently do not have such laws.

There are reasons why an internationally standardized and WTO-enforced competition policy - as currently on the agenda in the Doha Round of WTO trade negotiations - might not serve the interests of economic development. Since each country has unique considerations with respect to sectoral strength, national institutions of labour relations and social policy, and place in the world economy, it is hard to imagine that a uniform competition policy could serve the economic development strategies of all developing country members of the WTO. Most of these unique features relate to the underlying need of developing country for room to manoeuvre economically and politically to establish dynamic, rather than static, efficiency.

Competition policy in the industrialized countries arrived late relative to their level of economic development and, even then, has varied considerably across countries and been applied very selectively across sectors and interest groups in each country. This is not surprising, since all of these countries pursued economic development strategies that included considerable protectionist and anti-competitive behaviour in the effort to promote the development of domestic industrial capacity and to attain dynamic efficiency in the form of technological progress or its potential. As they formulate and revise their competition policies, developing countries today should draw from the lessons of the countries that have already achieved industrialization.

More competition is not always better, especially when the objective is technological progress, capital accumulation, economic growth and sustainable development. Technological innovation hinges on innovative effort, and such effort requires resources. In a perfectly competitive environment, firms break even by powerlessly charging the "going price". To charge a higher price is to risk collapse - thus the economic term "ruinous competition". According to Singh and Dhumale (1999, p. 12), "[u]nfettered competition may lead to price wars and ruinous rivalry and therefore may be inimical to future investment: from this perspective too much competition can be as harmful as too little". Rather than pursue a maximum degree of competition, countries should seek the optimum degree, that is, that amount of rivalry among firms that still generates profits such that firms are able to invest in innovation and other non-price dimensions of success. Oligopoly firms are able to price at a mark-up over costs and this mark-up can be determined, in part, by the investment needs of the firm, including those related to technological innovation. Competition policy should also not limit the state's ability to use industrial policy as described above. 
Developing countries should continue to build their own domestic competition policies, both to regulate domestic monopoly and to control the possible anti-competitive behaviour of transnational corporations. These same countries should enter discussions of a WTO-based international competition policy with much caution, as the potential costs of such an agreement are likely to outweigh the potential benefits. The benefits of a WTO-based agreement would possibly be in the ability to temper the anti-competitive effects of transnational affiliates. The costs will result from likely restrictions on countries' freedom to run targeted industrial policies, and to nurture domestic producers as they seek to move up the value chain of global production. There is a risk that the Doha Round of trade negotiations will lead to an agreement that will mainly serve the developed countries who want market access, in particular when where there are large private or state enterprises controlling an industry. According to Hoekman and Holmes (1999), a WTO-based agreement is unlikely to be helpful since:

The agenda is likely to be dominated by market access issues more than international antitrust [...]. The WTO process is driven by export interests (market access), not national welfare considerations, and there is no assurance that the rules that will be proposed or agreed will be welfare enhancing (Hoekman and Holmes, 1999, p. 16).

The developing country experience indicates that a WTO-enforced agreement on competition policy will be in the interest of developing countries only if: (a) it allows exclusion for the least developed countries; (b) it allows for a variety of domestic competition policy regimes like the developed countries themselves maintained over the past 50 years; (c) it allows adequate flexibility with respect to sectoral coverage and enforcement. Because such contingency and flexibility is almost impossible to negotiate and enforce at the level of the WTO, developing countries must be very careful not to sacrifice the tools for the attainment of dynamic efficiency at the cost of furthering the goal of static or allocative efficiency.

\title{
8.4 Raising labour standards
}

The "vertical disintegration" of production and its internationalization have made the location of production increasingly sensitive to labour cost differentials. According to Krugman (1995, pp. 336-337):

\begin{abstract}
It is often said that labour costs are now such a low share of total costs that low wages cannot be a significant competitive advantage. But when businesspeople say this, they do not mean that labour costs have declined as a share of value added: on the contrary, the division of value added between capital and labour has been impressively stable over time. What they mean, instead, is that because of the growing vertical disintegration of industry the value added by a given manufacturing facility is likely to be only a small fraction of the value of its shipments; and thus the labour share of that value added is also a small fraction of costs, which are dominated by the cost of intermediate inputs. But this vertical disintegration, or slicing up of the value chain, creates a greater, not smaller opportunity to relocate production to low-wage locations. In such an environment, the level of wage and non-wage labour standards has become a source of competition among firms and countries. ${ }^{53}$
\end{abstract}

\footnotetext{
${ }^{53}$ See Milberg and Elmslie (1997).
} 
The tying of minimum labour standards to market access or trade liberalization, for example through a WTO provision, is a contentious issue for developing-country governments, some of whom see their interest in keeping labour standards low so as to be able to compete internationally. While a low-wage/low-productivity regime may become a difficult "trap" to escape, it can also be a short-run solution to the problem of high unemployment and a lack of connection to international markets.

The fact that jobs in developing countries are increasingly connected to global production systems is a double edge for those who advocate raising the level of labour standards globally. On the one hand, to the extent that global production systems can be traced - say, from the small, home-based producer up to the large, lead-firm subcontractor - means that firms at the high end of the value chain could in principle be held accountable for labour conditions down through the complete global value chain. On the other hand, to the extent that global value chains are increasingly organized using arm's length or quasi-arm's length relations across firms in a given chain, then lead firms or top-tier supplier firms can more easily claim no responsibility for the labour conditions at the lower end of the value chain. Even opponents of the linking of trade liberalization to enforcement of a code of labour standards have tended to support the idea that countries might want to impose conditions on minimum labour or environmental standards on their own firms, even when those firms are operating abroad. Thus to the extent that global production systems work on arm's length rather than intra-firm relations, the regulation of a minimum set of labour standards would be outside the realm of control of any single firm or set of leading firms.

One way around this problem would be to enforce an expanded code of conduct on buyers at different levels of the value chain. Current and voluntary codes of conduct generally call for monitoring of supplier employment conditions. An extended code would require not just monitoring but specific conditions on those firms from which they purchase inputs. In this way, responsibility for labour standards cannot simply be passed down through the value chain and ultimately ignored at low levels of the chain. Lead firms and first-tier supplier firms could be held responsible for the labour standards among producers from whom they buy inputs, even if those input sellers are completely independent in terms of ownership rights. Moreover, by imposing labour standards by requiring firms to be accountable for the conditions among their suppliers, these lead firms would be unable to circumvent higher cost production because of higher standards adopted by one producer simply by moving to a lower cost and lower standard producer. Thus, encouraging lead or first-tier supplier firms to purchase from firms satisfying a minimum level of standards would, if adopted across a wide array of sectors, put a brake on any "race to the bottom" of global labour standards. 


\section{Conclusion}

This paper has argued that it is the change in the structure of trade - with more trade in intermediate as opposed to final goods - rather than the growth in trade volume per se that makes globalization an important phenomenon when it comes to the formulation of policies for economic development. This structural change in trade is the result of the emergence of global production systems, whereby parts and components of a good are produced in different locations around the globe. Of equal significance are the ownership characteristics of this structural change. While intermediate goods trade constitutes a rising share of world trade, intra-firm trade appears to make up a constant or falling portion of trade. Thus global production systems are increasingly characterized by arm's length relations between lead and supplier firms. It is argued that this shifting ownership pattern in global production systems is the result of the logic of lead firm competitive strategies. Lead firms outsource externally (i.e. outside the firm) those aspects of the production process which do not contribute to the firms' rents. These rents are typically associated with returns from proprietary, usually knowledge-based, assets, but may also arise from entry barriers and market power. The result of such externalization is the establishment of an asymmetry of market structures across the global production system - oligopolistic at the top end and more competitive at the lower. This paper posits that the theoretical implications of these forces calls for an abandonment of the theory of comparative advantage in favour of a theory of trade based on absolute advantage. Moreover, the focus on internalization in the theory of international production should shift toward an understanding of externalization.

Given the prominence of global production systems, the policy challenge is: how best to build economic and political institutions able to promote industrial upgrading and higher labour standards? This implies the need for measures to build large firms with the capacity to generate rents and investment in knowledge-based assets, but also subject to some competitive pressure, through the market or the mechanisms of reciprocal control. This will require an industrial policy to promote $R \& D$ and skill development in production and management. It will also be facilitated by a very specific competition policy, which may sacrifice some allocative efficiency in order to attain dynamic efficiency. Moreover, multinational enterprises have generally not been associated with the reinvestment of rents and the development of indigenous knowledge-based assets. Thus, special treatment for multinational enterprises does not usually promote dynamic efficiency and, most studies find, will not be effective in any case in attracting inward foreign investment. 



\section{Bibliography}

Agosin, M. and R. Mayer. 2000. "Foreign investment in developing countries: Does it crowd in domestic investment?”, Discussion Papers No. 159. Geneva: UNCTAD, May.

Akyuz, Y. and C. Gore. 1996. "The investment-profit nexus in East Asian industrialization", in World Development, 24(3).

Amadeo, E. 1998. "International Trade, Outsourcing and Labour: A View from the Developing Countries", Chapter 12 in Kozul-Wright, R. and R. Rowthorn (eds.), Transnational Corporations and the Global Economy. London: MacMillan.

Amsden, A. 1994. "A Descriptive Theory of Government Intervention in Late Industrialization”, in L. Putterman and D. Rueschemeyer (eds.), in The State and the Market in Development. Lynn Reiner.

. 1998. Asia’s Next Giant, New York: Oxford University Press.

. 2001. The Rise of the Rest: Challenges to the West from the Late-Industrializing Nations. New York: Oxford University Press.

Arndt, S. 1997. "Globalization and the Open Economy", in North American Journal of Economics and Finance, 8(1), 71-79.

. and H. Kierzkowski, (eds.). 2001. Fragmentation: New Production Patterns in the World Economy. Oxford University Press.

Bacha, E. 1978. “An Interpretation of Unequal Exchange from Prebisch-Singer to Emmanuel”, in Journal of Development Economics, 5, 319-330.

Bair, J. and G. Gereffi. 2001."Local Clusters in Global Chains: The Causes and Consequences of Export Dynamism in Torreon's Blue Jeans Industry", in World Development, 29(11), 18851903.

Balakrishnan, R. (ed.). 2002. The Hidden Assembly Line: Gender Dynamics of Subcontracted Work in a Global Economy. Bloomfield, CT: Kumarian Press.

Brainard, S. L. and D. Riker. 1997. “Are U.S. Multinationals Exporting U.S. Jobs?”, NBER Working Paper No. 5958, March.

Braunstein, E. and G. Epstein. 2002. "Bargaining Power and Foreign Direct Investment in China: Can 1.3 Billion Consumers Tame the Multinationals?", presented at CEPA, New School University, March.

Campa, J. and L. Goldberg. "The Evolving Export Orientation of Manufacturing Industries: Evidence from Four Countries”, NBER Working Paper No. 5919, February 1997.

Caves, R. 1982. Multinational Enterprise and Economic Analysis. Cambridge University Press.

Chaudhuri, T. and S. Adhikari. 1993. "Free Trade Zones with Harris-Todaro Unemployment: A note on Young-Miyagiwa", in Journal of Development Economics, 41, 157-62.

Christerson, B. and R. Appelbaum. 1995. "Global and local subcontracting: space, ethnicity, and the organization of apparel production", in World Development, 23(8), 1363-1374. 
Coase, R. 1937. "The Nature of the Firm", in Economica, 4, 386-405.

Cowell, A. 2002. "War Inflates Cocoa Prices But Leaves Africans Poor", in The New York Times, October 31, section C, p. 1.

Day, S. 2000. "Bargains are plentiful for shoppers this season", in The New York Times, December 21, first business page.

Deardorff, A. 2001. "Fragmentation across Cones", in S. Arndt and H. Kierzkowski, (eds.), Fragmentation: New Production Patterns in the World Economy, Oxford University Press.

Doremus, P., W. Keller, L, Pauly and S. Reigh. 1998. The Myth of the Global Corporation. Princeton: Princeton University Press.

Dosi, G., K. Pavitt, and L. Soete. 1991. The Economics of Technical Change and International Trade. New York: New York University Press.

Dunning, J. 2000. "The eclectic paradigm as an envelope for economic and business theories of MNE activity", in International Business Review, 9, 163-190.

Epstein and Burke. 2001. "Globalization and Labour Bargaining Power: A Survey", mimeo, PERI, University of Massachussetts-Amherst.

Ernst, D., J. Fagerberg and J. Hildrum. (2002) "Do Global Production Networks and Digital Information Systems make Knowledge Spatially Fluid?”, TIK Working Paper No. 13, University of Oslo.

Evans, P. 1995. Embedded Autonomy: States and Industrial Transformation. Princeton: Princeton University Press.

Fagerberg, J. 1996. "Technology and Competitiveness”, in Oxford Review of Economic Policy, 12(3), $39-51$.

Feenstra, R. 1998. "Integration of Trade and Disintegration of Production", in Journal of Economic Perspectives, Fall.

Feenstra, R. and G. Hanson. 1997 "Foreign Direct Investment and Relative Wages: Evidence from Mexico's Maquiladoras", in Journal of International Economics, 42(3/4), May, 371-439. . and _ 1999. "Productivity Measurement and the Impact of Trade and Technology on Wages: Estimates for the U.S., 1972-1990”, in Quarterly Journal of Economics, August, 114(3), 907-940.

. and _ 2001. "Global Production Sharing and Rising Wage Inequality: A Survey of Trade and Wages", mimeo, Feenstra web page, University of California-Davis.

Feenstra, R., W. Hai, W. Woo, S. Yao. 1998. "The U.S.-China Bilateral Trade Balance: Its Size and Determinants”, NBER Working Paper No. 6598.

Financial Times. 2000. "FT500”, in Financial Times, 4 May.

Fitter, R. and R. Kaplinsky. 2001. "Who Gains from Product Rents as the Coffee Market Becomes More Differentiated? A Value Chain Analysis", in IDS Bulletin, 32(3), 69-82.

Fortune. 2000. "The Fortune 500" annual issue. 
Frohlich, M. and R. Westbrook. 2001. "Arcs of integrations: an international study of supply chain strategies", in Journal of Operations Management, 19, 185-2000.

Gereffi, G. 1994. "The organization of buyer-driven global commodity chains", in Gereffi, G. and Korzeniewicz (eds.) (1994), in Commodity Chains and Global Capitalism. Westport, CT: Greenwood Press.

- 1999. "International Trade and Industrial Upgrading in the Aparel Commodity Chain", in Journal of International Economics.

. 2002. "Industrial Upgrading in Global Value Chains", paper presented at CEPA conference on Labour and the Globalization of Production, New School University, New York, March.

Glen, J., K. Lee, and A. Singh. 2002. "Corporate Profitability and the Dynamics of Competition in Emerging Markets: A Time Series Analysis", ESRC Centre for Business Research, University of Cambridge, Working Paper No. 248, December.

Gorg, H. and D. Greenaway. 2001. "Foreign Direct Investment and Intra-Industry Spillovers". Geneva: UNECE/EBRD Expert Meeting Paper, December.

Hanson, G. 2000. "Should Countries Promote Foreign Direct Investment?", Technical Working Paper for the G-24, UNCTAD, Geneva.

. and A. Harrison. 1999. "Trade, Technology and Wage Inequality", in Industrial and Labour Relations Review, 52(2), 271-288, January.

, R. Mataloni and M. Slaughter. 2001. "Expansion Strategies of U.S. Multinational Firms", mimeo.

Harrison, B. and M. Kelley. 1993. "Outsourcing and the Search for Flexibility”, in Work, Employment and Society, 7, June.

Hertel W. Thomas and M. Will. 1999. Developing Country Interests in Liberalizing Manufactures. Purdue University, World Bank.

Hoekman, B. and P. Holmes. 1999. "Competition Policy, Developing Countries and the WTO", World Bank Working Paper.

Holmstrem, B. and J. Roberts. 1998. "The Boundaries of the Firm Revisited", in Journal of Economic Perspectives, 12(3), Fall, 73-94.

Howell, D., E. Houston and W. Milberg. 2001. "Demand Shifts and Wage Inequality: A Jobs-Based Assessment of the Conventional Supply and Demand Model", in J. Stanford, et al. (eds.), in Power, Employment and Accumulation. Armonk, NY: M.E. Sharpe.

Hummels, D., D. Rapoport and K. Yi. 1998. "Vertical Specialization and the Changing nature of World Trade", in FRBNY Economic Review, June, 79-99.

Hymer, S. 1976. The International Operations of National Firms: A Study of Direct Foreign Investment. Cambridge: MIT Press.

International Monetary Fund, World Economic Outlook data base:

http://www.imf.org/external/pubs/ft/weo/2001/01/data/ 
Jenkins, M., G. Esquivel, and F. Larrain. 1998. "Export Processing Zones in Central America", Development Discussion Paper No. 646, Harvard Institute for International Development, August.

Jones, R. 1980. "Comparative and Absolute Advantage", in Schweizerische Zeitschrift fur Volkswirtschaft und Statistik, September, 235-260.

. 2000. Globalization and the Theory of Input Trade. Cambridge: MIT Press.

Kaplinsky, R. 1993. "Export Processing Zones in the Dominican Republic: Transforming Manufacturers into Commodities", in World Development, 21(11), 1851-1865.

Krugman, P. 1991. "Myths and Realities of U.S. Competitiveness", in Science Magazine, November, 811-815.

. 1995. "Growth in World Trade: Causes and Consequences", in Brookings Papers in Economic Activity, 1995:1, 327-377, PEA.

Kucera, D. 2002. Core Labour Standards and Foreign Direct Investment, mimeo, International Labour Organization.

. and W. Milberg. 2003. "Deindustrialization and Changes in Manufacturing Trade: Factor Content Calculations for 1978-1995", in Weltwirstshaftliches Archiv, forthcoming.

Martins, J. and S. Scarpetta. 1999. "The levels and cyclical behaviour of mark-ups across countries and market structures”. Paris, OECD, Economics Department Working Papers No. 213.

Mataloni. 2000. "An Examination of the Low Rates of Return of Foreign-owned U.S. Companies", in Survey of Current Business, March, 55-73.

Mayer, J., A. Butkevicius and A. Kadri. 2002. "Dynamic Products in World Exports", UNCTAD Discussion Paper No. 159, Geneva.

Milberg, W. 1999. "Foreign Direct Investment and Development: Balancing Costs and Benefits", in International Monetary and Financial Issues for the 1990s, Vol. XI, New York: United Nations.

. and B. Elmslie. 1997 "Harder than you think: Free trade and International Labour Standards", New Labour Forum, Fall.

Ng, F. and A.Yeats. 1999. "Production Sharing in East Asia: Who does What for Whom and Why?", mimeo, The World Bank.

Nolan, P., D. Sutherland and J. Zhang. 2002. The Challenge of the Global Business Revolution, mimeo. Cambridge University.

OECD (1999 and updates) in Economic Outlook, No. 66, Paris.

Palpaceur, F. 2002. "Global Value Chains : Note for Discussion”, mimeo. Geneva : ILO, September.

Pessino, C. 1995. The Labour Market During the Transition in Argentina, Buenos Aires: CEMA, mimeo.

Porter, M. 1990. The Competitive Advantage of Nations. New York: The New Press.

Powell "Neither Market nor Hierarchy: Network Forms of Organization", in Research in Organization Behavior, Straw, B. and L. Cummings (eds.), 1990. 
Ricardo, D. 1981. The Collected Works of David Ricardo, Volume 1: The Principles of Political Economy and Taxation, by P. Sraffa (ed.). Cambridge University Press.

Robbins, D. 1996. Evidence on Trade and Wages in the Developing World. Paris: OECD.

Roberts, M. and J. Tybout. 1996. "A Preview of the Country Studies", Chapter 8 in Roberts, M. and J. Tybout, (eds.), Industrial Evolution in Developing Countries. Oxford University Press for the World Bank, 1996.

Rodrik, D. 1999. Making Openness Work. Washington: Overseas Development Council.

Rose, A. 1991. "Exchange Rates and the Trade Balance: Evidence for 6 Industrialized Countries", in Journal of International Economics.

Samuelson, P. 1949. “International Factor-Price Equalization Once Again”, in Economic Journal, 234.

Semmlinger, K. 1991. "New Developments in Subcontracting: Mixing Market and Hierarchy", Ch. 5 in A. Amin and M. Dietrich, (eds.), Towards a New Europe? Structural Change in the European Economy. Aldershot: Edward Elgar.

Singh, A. and R. Dhumale. 1999. "Competition Policy, Development and Developing Countries", South Centre Working Paper No. 7.

Slaughter, M. 2002. "Skill-Upgrading in Developing Countries: Has Inward Foreign Direct Investment Played a Role?", paper presented at conference at CEPA on Labour and the Globalization of Production, New School University, March.

Sturgeon, T. 2001. "How Do We Define Value Chains and Production Networks?", in IDS Bulletin, 32(3), July.

. 2002. "Modalities of governance in global value chains", Competition and Change.

te Velde, D. and C. Morrissey. 2001. "Foreign Ownership and Wages: Evidence from five African

Countries", CREDIT Discussion Paper 01/19:

www.nottingham.ac.uk/ economics/ research/credit).

Tybout, J. 2000. "Manufacturing Firms in Developing Countries: How Well Do They Do, and Why?", in Journal of Economic Literature, 38, March, pp. 11-44.

UNCTAD. 1993, 1998, 2001, 2002a. World Investment Report. Geneva.

. 2002b. Trade and Development Report. Geneva.

United States Department of Commerce. 2002. National Income and Product Accounts Tables, Bureau of Economic Analysis, Washington. http://www.bea.gov/ bea/ai/iidguide.htm

. Survey of Current Business, Bureau of Economic Analysis, Washington.

. Census Bureau's FT-900, U.S. International Trade in Goods and Services, annual issues.

Venables, A. 2002. "Vertical Specialization", mimeo. Geneva: ILO.

Wheeler, D. and A. Mody. 1992. "International investment location decisions: The case of U.S. firms", in Journal of International Economics, 33. 
Williamson, O. 2002. "The Theory of the Firm as Governance Structure: From Choice to Contract", in Journal of Economic Perspectives, 16(3), Summer, pp. 171-195.

World Bank. 2000, 2001. Global Development Finance database.

. 2002. A New Database on Foreign Direct Investment.

http://wwwl.worldbank.org/economicpolicy/globalization/data.html.

World Trade Organization. 2002. International Trade Statistics 2002.

http://www.wto.org/english/res_e/statis_e/its2002_e/its02_longterm_e.htm

Yeats, A. J. 2001. "Just How Big Is Global Production Sharing?", in S. Arndt and H. Kierzkowski (eds.), 2001, Fragmentation: New Production Patterns in the World Economy. Oxford University Press.

Ziegler, C. 2001. “The Global Garden”, mimeo. Department of Anthropology, Graduate Faculty. 


\section{Policy Integration Department Working Papers prepared for the World Commission on the Social Dimension of Globalization}

No. 16 International finance: Meeting the needs of people in developing countries, José Guilherme Almeida dos Reis

No. 17 The gender dimensions of the globalization of production, Stephanie Barrientos, Naila Kabeer and Naomi Hossain

No. 18 Social exclusion in the context of globalization, Jan Breman

No. 19 Gender and globalization: A macroeconomic perspective, Çağatay Nilüfer and Ertük Korkurt

No. 20 Globalization, social exclusion, and work: with special reference to informal employment and gender, Marilyn Carr and Martha Chen

No. 21 Resources for social development, Anthony Clunies Ross

No. 22 Does the new international trade regime leave room for industrialization policies in the middle-income countries?, Alisa DiCaprio and Alice Amsden

No. 23 Social dimension of globalization in Latin America: Lessons from Bolivia and Chile, Alvaro García Hurtado

No. 24 Globalization: Social impact and policy actions: A partly annotated bibliography, Bernhard Gunter and Rolph van der Hoeven

No. 25 The social dimension of global production systems, Susan Hayter

No. 26 Reforming global economic and social governance: a critical review of recent programmatic thinking, Jeremy Heimans

No. 27 Corporate social responsibility: An issues paper, Michael Hopkins

No. 28 Upgrading in global value chains, John Humphrey

No. 29 Implications of globalization and economic restructuring for skills development in Sub-Sahara Africa, Richard K. Johanson

No. 30 The outcome and impact of the main international commissions on development issues, Frédéric Lapeyre

No. 31 Globalization and structural adjustment as a development tool, Frédéric Lapeyre

No. 32 Globalization and perceptions of social inequality, Malte Luebker

No. 33 The changing structure of trade linked to global production systems: What are the policy implications?, William Milberg

No. 34 Corporate social responsibility: An overview of principles and practice, Jill Murray

No. 35 Inclusive development strategy in an era of globalization, Ignacy Sachs

No. 36 Social consequences of the globalization of the media and communications sector: Some strategic considerations, Seán Ó. Siochrú

No. 37 Globalization, history and international migration - A view from Latin America, Andrés Solimano

No. 38 Towards a different kind of globalization, or how the anti-globalizers view the world, Gijsbert van Liemt 